\title{
CHILD-CUSTODY ADJUDICATION: JUDICIAL FUNCTIONS IN THE FACE OF INDETERMINACY*
}

\author{
ROBERT H. MNOOKIN†
}

\section{INTRODUCTION}

Four issues have dominated much of the academic discussion of childcustody law during recent years. The first, and perhaps most conspicuous, centers on how much weight should be given to the interests of the natural parents in custody disputes involving third parties. ${ }^{1}$ Although statutory provisions and appellate opinions do not accurately measure how the judicial process in fact works in the custody area, they do suggest that trial courts may now use the best-interests-of-the-child standard and such new concepts as "psychological parenthood" to reject the claims of a child's natural parents.

The second issue concerns the degree to which the legal standards for the resolution of custody disputes should be discretionary. Over ten years ago, Professors Foster and Freed wrote that nowhere has the task of achieving "a work-

* 1976 by the author.

$\dagger$ Professor of Law, University of California, Berkeley; former Director, Childhood and Government Project, Earl Warren Legal Institute, University of California, Berkeley. Research for this article was supported by grants to the Childhood and Government Project from the Ford Foundation and the Carnegie Corporation of New York.

I wish gratefully to acknowledge the help of Gary Bostwick, Paula Downey, Penny Fuhrman, Lewis Kornhauser, James Mosher, and Jean Waltzer, each of whom, as a law student, was my research assistant at one time or another while 1 did research for this article. So many of my colleagues here at Berkeley made helpful comments on earlier drafts that the list of their names would be pretentiously and embarrassingly long. For their counsel and support, 1 am very grateful. Finally, I would like to thank Joe Feldman (who generously read and commented on more drafts than either of us cares to remember), Spiros Simitis, Victor Goldberg, Norman Dorsen, Brigitte Bodenheimer, and Michael Wald for their helpful suggestions.

1. See, e.g., Comment, Alternatives to "Parental Right" in Child Custody Disputes Involving Third Parties, 73 Yale L.J. 151 (1963); J. Goldstein, A. Freud, \& A. Solnit, Beyond the Best Interests of The Child (1973) [hereinafter cited as Goldstein, Freud, \& Solnit]; Foster \& Freed, Child Custody, 39 N.Y.U.L. Rev. 423, 615, 630 (1974); Comment, Child Custody-Rebutting the Presumption of Parental Preference, 43 Miss. L.J. 247 (1972); Comment, Custody of Children: Best Interests of Child vs. Rights of Parents, 33 Calif. L. Rev. 306 (1945); Note, A Fit Parent May Be Deprived of Custody of His Child if the Best Interest and Welfare of the Child Would Be Served by Allowing Another Person to Raise Him, 4 Houston L. Rev. 131 (1966); Note, Domestic Relations-Custody of a Minor-Best-Interest-of-the-Child Rule, 32 Tul. L. Rev. 499 (1958); Note, Domestic Relations: Child Custody-Parent v. Third Party in Kansas, 13 Washburn L.J. 228 (1974).

2. See, e.g., statutes cited in notes 50 and 51 infra; In re B.G., 11 Cal. 3d 679, 523 P.2d 244, 114 Cal. Rptr. 444 (1974), discussed in text at notes 108-25 infra. 
more challenging than in the area of child custody."3 In the last decade, while some commentators have attacked the breadth of discretion granted judges in resolving custody disputes, the limited role of appellate review, and the inadequate protection of normal procedural safeguards, ${ }^{4}$ courts, legislators, and other commentators have shown enormous hostility towards the development of rules that provided tight substantive standards for custody disputes. The differences among families generate great pressure to treat each case on its own facts. Indeed, the old presumptions and rules based on the sex of the parent, the age of the child, or the status of a contestant as a natural parent have all been criticized. ${ }^{5}$ Although some commentators have suggested rules are needed, ${ }^{6}$ American custody law has come to require a highly individualized determination of what is in the best interests of (or least detrimental to) a particular child. ${ }^{7}$

The third issue concerns how the standards for the resolution of custody disputes can be simplified to avoid the complexities of existing law. Custody law today reflects a complicated and chaotic multiplicity of such factors as the doctrinal thread invoked, the identity of the disputants, their prior relationship to the child, and the setting from which the dispute arose. Most states have four separate strands of law that can be used to resolve a custody dispute: (1) divorce law, (2) guardianship law, (3) juvenile court child-neglect laws, and (4) laws relating to termination of parental rights to free a child for adoption. Typically, no single court has jurisdiction over all four strands. ${ }^{8}$ Each strand is invoked most often between particular kinds of parties, but the strands often have overlapping application. "Moreover, the term "custody" is itself ambiguous because each of the four normally carries different legal im-

3. Foster \& Freed, supra note 1, at 423.

4. See,e.g., R. Levy, Uniform Marriage and Divorce Legislation: A Preliminary Analysis, 222-46 (1968); Foster \& Freed, supra note 1; Sullivan, Child Neglect: The Environmental Aspects, 29 Ohio State L.J. 85 (1968); Mnookin, Foster Care-In Whose Best Interests, 43 Harv. Ed. Rev. 599 (1973); Wald, State Intervention on Behalf of Neglected Children: A Search for Realistic Standards, 27 Stan. L. Rev. 985 (1975).

5. See Comment, Measuring the Child's Best Interests-A-Study of Incomplete Considerations, 44 Denver L.J. 132, $145-46$ (1967); cf. Oster, Custody Proceeding: A Study of Vague and Indefinite Standards, 5 J. Family Law 21, 37-38 (1965); Watson, The Children of Armageddon: Problems of Custody Following Divorce, 21 Syracuse L. REv. 55, 82 (1969). See also sources cited in note 1 supra.

6. See, e.g., R. LevY, supra note 4; Ellsworth \& Levy, Legislative Reform of Child Custody Adjudication, 4 LAw \& Soc'y REv. 167, 202-03 (1969); Mnookin, supra note 4; Wald, supra note 4.

7. See text at notes 22-107 infra.

8. In California, for example, a superior court has jurisdiction for divorce, Cal. Civ. Code $\S$ 4351 (West Supp. 1975), and adoptive custody, Cal. Civ. Code $\S 226$ (West Supp. 1975); a probate court has jurisdiction for guardianship, Cal. Prob. Code $\S 1405$ (West Supp. 1975); and a juvenile court has jurisdiction for neglect, CAL. WELF. \& lNST'NS Code $\$ 600$ (West 1972). This pattern is not unusual. For an excellent discussion of the procedural complexities created by the jurisdictional conflicts in California, see Bodenheimer, The Multiplicity of Child Custody Proceedings-Problems of California Law, 23 Stan. L. Rev. 703, 706-21 (1971).

9. For example, while disputes between two natural parents normally involve divorce custody law, each of the other three strands has, on occasion, been invoked to control or eliminate custo- 
plications for the parent-child relationship. ${ }^{10}$ One concerned primarily with the child, and not with the impact on the parents of the legal consequences of the proceedings, would find the "fortuity" of the strand of custody law invoked an unacceptable basis for applying a different legal standard. As a result, many reformers, impatient with the already faded differences among the legal standards applied to different sorts of custody cases, call for a single standard or set of standards for all custody disputes. ${ }^{11}$ The preferred standard usually requires an individualized determination of what is in the best interests of ${ }^{12}$ (or least detrimental to) ${ }^{13}$ a particular child.

The fourth issue concerns who should decide custody disputes and by what process. Are custody disputes, by their very nature, somehow inappropriate for resolution by adjudication? Adversary proceedings are said to distort the fact-finding process in custody disputes and unnecessarily injure the parties. ${ }^{14}$ Commentators have argued that judges are ill-equipped to make the necessary determinations ${ }^{15}$ and that social workers, psychologists, or psychiatrists should have a more important role in the ultimate decision, ${ }^{16}$ perhaps as part of a family court. ${ }^{17}$

dial rights. See, e.g., In re Burket, 58 Cal. App. 2d 726, 137 P.2d 475 (1943) (child over fourteen years of age nominated noncustodial father as guardian to defeat original divorce custody award to mother); In re Anonymous, 37 Misc. 2d 41 1, 238 N.Y.S.2d 422 (Rensselaer County Family Ct. 1962) (father challenged mother's custody in neglect proceeding); In re Clark, 183 N.W.2d 179 (Iowa 1971) (mother opposed adoption by father's new spouse). Similarly, a custody dispute between a parent and nonparent may involve any of the four strands. See, e.g., Dyer v. Howell, 212 Va. 453, 134 S.E.2d 789 (1971) (adoptive parents against father); Trenton v. Christ, 216 Md. 418 , 140 A.2d 660 (1958) (father against custodial grandparent); In re B.G., 11 Cal. 3d 679, 523 P.2d 244, 114 Cal. Rptr. 444 (1974) (foster parents against mother); In re Bock, 280 N.Y. 349,21 N.E.2d 186 (1939) (brother of deceased father against noncustodial mother).

10. In an ongoing, two-parent family, the parents together have the right to live with, supervise, care for, and educate the child; to consent to the child's medical treatment; and to have child's earnings. See, e.g., Del. CODE ANN. tit. 1?, $\$ \S 701,703$ (1975). Until very recently, the father was generally made primarily liable for the support of his child, with the mother liable if the father failed in his duty. See, e.g., Cal. Civ. Code $\$ 196$ (West 1954); N.Y. Dom. ReL. Law $\S$ 32 (McKinney 1964); Del. Code ANN. tit. 13, \& 702 (1975). More recently, some statutes have made both the mother and father equally responsible for the support of their children. See, e.g., IOWA CODE $\$ 252.2$ (1971). These various elements of the parent-child relationship are affected differently, depending upon the strand of law used to resolve a "custody" dispute. See text at notes 22-107 infra. See also Sayre, Awarding Custody of Children, 9 U. CHI. L. Rev. 672 (1942).

11. See text at notes $108-25$ infra.

12. See, e.g., H. Clark, The Law of Domestic Relations in the United States 572 (1968): "The unifying principle which runs through the cases is that custody must be so awarded as to promote the child's best interests. The bald statement is too general to be helpful, but it can be given meaning by an examination of the cases such as is here proposed. The subject of this chapter therefore is the manner in which the courts have gone about applying this principle to the infinite variety of custody conflicts."

13. See Goldstein, Freud, \& Solnit 53-64, discussed in text at notes 111-24, 227 infra.

14. See, e.g., Foster \& Freed, supra note 1, at 627; Watson, supra note 5, at 58.

15. See, e.g., Goldstein, Freud, \& Solnit 49-52; President's Comm. on Law Enforcement and the Administration of Justice, Task Force Report on Juvenile Delinguency and Youth Crime 7 (1967); Kay, A Family Court: The California Proposal, 56 Calif. L. Rev. 1205, 1208 (1968); Watson, supra note 5, at 61-64.

16. See, e.g., Foster \& Freed, supra note 1, at 627.

17. See, e.g., id.; Kay, supra note 15, at 1225-32. 
This paper develops two themes to provide some perspective on and better understanding of all four of these core issues. The first theme is that the determination of what is "best" or "least detrimental" for a particular child is usually indeterminate and speculative. For most custody cases, existing psychological theories simply do not yield confident predictions of the effects of alternative custody dispositions. Moreover, even if accurate predictions were possible in more cases, our society today lacks any clear-cut consensus about the values to be used in determining what is "best" or "least detrimental."

The second theme is that courts perform two very different functions ${ }^{18}$ in the resolution of custody disputes: private-dispute-settlement and childprotection. The private-dispute-settlement function is involved when the court must choose between two or more private individuals, each of whom claims an associational interest with the child. While such a dispute is ordinarily between adults, it obviously also affects the child. The characterization of this function as "private" does not imply that a court should treat a child as an "object" and consider only the interests of the adults. By providing a judicial forum, the state protects the substantial public interest in resolving such disputes without resort to private force or violence and also protects the expectations and interests of the individuals directly affected, including the child. The second function, child-protection, involves the judicial enforcement of standards of parental behavior believed necessary to protect the child. ${ }^{19}$ This function is consistent with the well established principle that the parens patriae power of the state empowers courts to remove children from parental custody if that is necessary for their protection.

To recognize that a child's best interests are usually indeterminate and that courts in custody disputes may perform two distinct functions will cer-

18. I am employing the word "function" both in a descriptive way (i.e., to point out an observed relationship between certain social conditions before and after the operation of the process of adjudication) and in a "normative" sense (i.e., to suggest what the object of the process should be). The analytical distinction offered between dispute settement and child protection is descriptive because it seems to be helpful in understanding and analyzing child-custody adjudication, but it has normative implications as well. Merton's distinction between "manifest" and "latent" function, see id. at 51 , is useful to understand why. Both the child-protection function and the disputesettlement function are manifest (i.e., they are intended and recognized by the participants in the system of action concerned), but imperfectly so. My argument is that these functions should be more manifest: in other words, both the actors in the system and the legal rules should recognize and distinguish between these functions more explicitly, so that the legal process can be made to pursue each more purposefully.

I recognize that the concept of a "function" is often used ambiguously and is the subject of extensive scholarship both in the biological and social sciences. See, e.g., J. WOOdGER, BIOLOGICAL Principles: A Critical Study 326-30 (1929); R. Merton, Social Theory and Social StrucTURE 20-25 (rev. ed. 1958). Untangling the variety of definitions that have been offered or offering my own comprehensive definition is unnecessary for the purposes of this article.

19. Admittedly, if one defines child protection as requiring the state to do what is best for a child, then this function would be involved in every child-custody dispute. For reasons explored later in this article, I reject such an expansive definition of child protection. See text at note 184 infra. 
tainly not solve all the dilemmas of custody law. Indeed, recognition of the indeterminacy of present-day standards brings into sharp focus a deeply cutting dilemma. Because what is in the best interests of a particular child is indeterminate, there is good reason to be offended by the breadth of power exercised by a trial court judge in the resolution of custody disputes. But the underlying reasons for this indeterminacy-our inability to make predictions and our lack of consensus with regard to values-make the formulation of rules especially problematic. In all events, the debate over rules versus discretion is best understood when the indeterminacy of what is best is candidly admitted. Moreover, examination of the reasons for this indeterminacy suggests that procedural changes in custody disputes, greater use of experts, or a change in the nature of the forum may avoid some mistakes and make the process more fair but will not correct the underlying difficulty.

While a single case may involve both functions, the distinction between the private-dispute-settlement function of courts and the child-protection function is useful. It provides a basis for exploring both the implications of the indeterminacy of the "best-interests" and "least detrimental" standards and the questions of whether rules are feasible and would be better than broadly discretionary standards. The distinction also provides a basis for criticism of the doctrinal distinctions among the varieties of custody law that have troubled many reformers. Equally important, the distinction can be used to show why, in the face of indeterminacy, it is both unjust and unwise to simplify and rationalize custody law by adopting a single standard that necessarily confuses these two separate functions.

Part I of this article provides necessary background by describing and analyzing the varieties of American custody law. Each of the four strands of present-day custody law is identified, and the legal consequences and typical context for each are described. Some generalizations are offered about the underlying substantive standards used to resolve custody disputes. Part II demonstrates the basic indeterminacy of present-day legal standards, after contrasting the resolution of a custody dispute pursuant to such standards with the tasks normally assigned to courts for adjudication. Part III analyzes the consequences of this indeterminacy and explores the desirability and feasibility of developing less discretionary legal standards for each of the two judicial functions, child-protection and private-dispute-settlement.

\section{I}

The Varieties of Custody Law

A. The Four Strands and the Discretionary Nature of Contemporary Custody Standards

Three generalizations emerge from the following analysis of the underlying substantive standards used by courts to decide custody disputes. Each is 
based in part on historical comparisons, and each is related to the bestinterests-of-the-child standard. The first, and most important, concerns the specificity of the controlling legal standards. In the past two centuries, we have moved from a pattern of treating a child as a possession or a "thing" to be owned to a much more child-centered mode of analysis. Parallel with this, previously sharp rules have dissolved, and controlling legal standards have become less specific. ${ }^{20}$ In varying degrees, each of the four strands of childcustody law provides the trial judge with substantial discretion-i.e., freedom to make a choice among possible courses of action or inaction without effective limitation. ${ }^{1}$ Second, the standards are becoming more "neutral" in two ways. In disputes between parents, rules or presumptions favoring either parent on the basis of sex are giving way to an allegedly neutral application of

20. To evaluate controlling legal standards by their degree of specificity, the distinction between legal rules and legal principles is useful. A rule is "a legal direction which requires for its application nothing more than a determination of the happening of physical or mental events - that is determination of fact." H. Hart \& A. Sacks, The Legal Process 155, 1958 (unpublished manuscript in Harvard Law School Library). See also id. at 155-60; 2 R. Pound, Jurisprudence 124 (1959). A rule, according to Ronald Dworkin, is "applicable in an all-or-nothing fashion. If the facts a rule stipulates are given, then either the rule is valid, in which case the answer it supplies must be accepted, or it is not, in which case it contributes nothing to the decision." Dworkin, The Model of Rules, 35 U. CHI. L. REv. 14, 25 (1967).

Principles, on the other hand, require substantial elaboration if they are to be used to decide a case. "[Principles] are not expressed in terms of the happening or non-happening of physical or mental events or of qualitative appraisals of such happenings drawn from ordinary human experience. They are on a much higher level of abstraction, and obviously involve a vastly larger postponement of decision." H. Hart \& A. Sacks, supra at 159. See also Dworkin, supra at 27. While a principle provides a purpose or objective, it leaves a decision-maker the task of figuring out how to achieve that objective and the weight to be accorded to that objective when there are other principles pointing in other directions. See H. Hart \& A. Sacks, supra at 158-60; Dworkin, supra at 27. While Dworkin and Hart and Sacks subdivide nonrules into policies and principles, see Dworkin, Hard Cases, 88 HARv. L. Rev. 1057 (1975); H. Hart \& A. Sacks, supra at 158-60; this further distinction is not important for present purposes.

Dworkin's definitions were developed for the purpose of showing that the positivist position of H.L.A. Hart and others could not explain the discretionary aspects of the judicial role in a world where principles (as defined by Dworkin) are so often the legal standards. For critical comments on Dworkin's article, as well as Dworkin's response, see Raz, Legal Principles and the Limits of Law, 81 YALE L.J. 823 (1972); Dworkin, Social Rules and Legal Theory, 81 Yale L.J. 855 (1972).

21. See K. Davis, Discretionary Justice 4 (1969). Legal standards can be seen as ranging across a wide and continuous scale, with a pure legal rule (requiring only the determination of a past "fact") at one extreme and an extremely open-ended principle at the other. As one moves along the scale, the individual charged with decision has greater discretion. See M. Eisenberg, Modes of Dispute Settlement 10-11 (unpublished manuscript on file at School of Law. University of California, Berkeley). Cf. Dworkin, The Model of Rules, supra note 20.

Dworkin distinguishes between three possible meanings of discretion: (1) a "weak" version, suggesting only that the decision-maker must exercise judgment and choose; (2) a second "weak" version, reflecting the degree to which the decision-maker's choice will be subject to review or modification by others; and (3) a third "strong" version, present when a judge is "not controlled by a standard" that is to be applied. Id. at $32-35$. A trial judge in a custody dispute plainly has discretion in the first sense; and he has a substantial degree of discretion in the second sense, because appellate review is so limited in custody cases. See text at notes 143-48 infra. In applying the best-interests-of-the-child standard, a judge apparently has discretion in Dworkin's strong sense as well, because the best-interests standard is not a rule and is not determinative of a rule. 
the best-interests-of-the-child principle. And the appeal to the same broad principle is being used in some degree to justify denying the custodial rights of a natural parent challenged by an nonparent or a state official. And third, the four strands of custody law are not doctrinally pure. Indeed, recent judicial, legislative, and scholarly works portend substantial pressure for a single set of legal standards for all custody disputes.

\section{Divorce Custody Law}

Most child-custody disputes requiring judicial resolution arise out of the dissolution of marriage. When a child's parents live together, the issue of which parent has the right to custody does not arise. But when each parent has a separate household, they may disagree about who should have primary responsibility for caring for the child. If a divorce is granted, a court at that time normally will determine who will subsequently have custody. ${ }^{22}$ Courts resolve disputes between parents before ${ }^{23}$ or after ${ }^{24}$ divorce as well. A substantial body of law (which is here styled "divorce custody law") provides standards for the resolution of such disputes. Although it normally applies to disputes simply between two parents, the occasion of divorce may lead some other relative or friend to ask for custody as well. ${ }^{25}$ In all events, the application of divorce custody law nearly always involves the private-disputesettlement function, for there are competing private parties-usually the child's parents-seeking custody on the basis of their relationship to the child; but when the court must evaluate a claim that one of the parties would endanger the child, the child-protection function may be involved as well.

22. See, e.g., Ohio Rev. Code Anv. \$ 3109.04 (Page Supp. 1974); Wis. Stat. Anv. \$ 247.24 (Supp. 1974). While scanty and out of date, existing evidence suggests that when a child's mother and father no longer wish to remain together, there is usually either no dispute over which parent should have primary responsibility for the children or, if there is, it is resolved without the need for a judicial determination. See W. Goode, After Divorce 313 (1956) (discussed at note 189 infra). The decree formally dissolving a marriage may require judicial confirmation of the custody question, see, e.g., Conn. Gen. STAT. Rev. \$ 46-49 (1975); but few divorce proceedings involve contested custody issues. Although the court is not bound to accept the parents' agreement with regard to custody, see, e.g., Puzzuoli v. Puzzuoli, 3 Mich. App. 594, 143 N.W.2d 162 (1966); the courts usually rubber-stamp the parties' own decision. See W. Goode, supra.

23. See, e.g., Мich. Comp. Laws $\S 552.15$ (1967); S.D. Comp. Laws $\$ 25-4-45$ (1969); Wis. Stat. Ann. $\$ 247.23$ (1) (Supp. 1974). Whether or not a petition for legal separation or divorce has been filed, there can be a judicial resolution of custody disputes. See, e.g., ILl. Axv. Stat. ch. 3, $\S$ 132 (Smith-Hurd 1961) ("If the parents live apart, the court for good reason may award the custody and education of the minor to either parent or to some other person"); WASH. REV. CODE $\$ 26.09 .200$ (1974).

24. See, e.g., Мich. Comp. Laws \$ 552.17 (1967); S.D. Comp. Laws \$ 25-4-45 (1969); Wis. Stat. AnN $\$ 247.25$ (Supp. 1974).

25. See, e.g., Smith v. Smith, 365 Mich. 122, 111 N.W.2d 806 (1962); Haynes v. Haynes, 191 S.W.2d 81 (Tex. Civ. App. 1945). See also Note, Domestic Relations: Child Custody--Parent a. Third Party in Kansas, 13 Washburn L.J. 228 (1974); Comment, Alternatives to "Parental Right" in Child Custody Disputes Involving Third Parties, 73 YALE L.J. 151 (1963). 
When courts award "custody" incident to separation or divorce, the winner usually has less than all the rights included in custody within the on-going two-parent family. In some cases, the parents can have joint custody, with the child periodically living with each parent. ${ }^{26}$ More typically, however, only one parent has custody, and that parent lives with and decides about the care and education of the child,${ }^{27}$ including religious training. ${ }^{28}$ Such custody is usually subject to the other parent's rights of visitation. Moreover, the divorce decrce can provide that the noncustodial parent must be consulted or must consent before certain important decisions are made about the child's education. ${ }^{29} \mathrm{Fi}$ nally, the duty of support is often separated from the right to have the child live with the particular parent. ${ }^{30}$ In short, divorce custody law permits courts great flexibility in dividing the various legal elements of the parent-child relationship.

The history of the legal standards governing custody disputes between a child's parents reveals a dramatic movement from rules to a highly discretionary principle gradually shorn of narrowing procedural devices. ${ }^{31}$ In the early

26. See, e.g., State ex rel. Sprague v. Bucher, 38 Tenn. App. 40, 270 S.W.2d 565 (1953). Traditionally, courts have viewed divided custody as undesirable, absent exceptional circumstances. See, e.g., McLemore v. McLemore, 346 S.W.2d 722 (Ky. 1961); McDermott v. McDermott, 192 Minn. 32, 255 N.W. 247 (1934). See also Annot., 92 A.L.R.2d 695 (1961). The psychological and legal problems related to divided custody are discussed in Note. Divided Custody of Children After Their Parents' Divorce, 8 J. Family Law 58 (1968).

27. See, e.g., Jenks v. Jenks, 385 S.W.2d 370 (Mo. Ct. App. 1964) (custodian's right to determine child's education); $c f$. WIS. STAT. AnN. \$247.24(2)(a) (Supp. 1974) (custodian's power and duty to authorize necessary medical care).

28. See, e.g., Paolella v. Phillips, 27 Misc. 2d 763, 209 N.Y.S.2d 165 (Sup. Ct. 1960); Donahue v. Donahue, 142 N.J. Eq. 701, 61 A.2d 243 (Ct. Err. \& App. 1948). Examination of reported appellate cases would suggest that differences over religion are an important source of custody disputes. See generally Annot, 66 A.L.R.2d 1410 (1959).

29. See, e.g., Van Nortwick v. Van Nortwick, 87 Ill. App. 2d 55, 230 N.E.2d 391 (1967).

30. See, e.g., N.C. GeN. STAT. $§ 50-13.4$ (Supp. 1974); Sanders v. Sanders, 167 N.C. 319,83 S.E. 490 (1914).

31. The breadth of a legal principle and the degree of discretion may narrow over time. Although a court may initially be confronted with a broad principle, the process of reconciling the case at hand with prior cases and elaborating what Professor Jaffe has called "intermediate premises" can narrow the breadth of a principle and judicial discretion. Jaffe, Was Brandeis an Activist? The Search for Intermediate Premises, 80 HaRv. L. REv. 986 (1967). In addition, a broad principle may be considerably narrowed in practice because of various "procedural" devices: a presumption, the burden of going forward, the risk of nonpersuasion, or the level of proof can all significantly affect the probable outcome of a dispute, particularly if the underlying determination is one necessarily clouded by doubt.

In a number of areas of law, one might be able to demonstrate an evolution of legal standards from fixed rules to the more flexible use of principles. John Noonan has suggested, for example, such a movement with regard to Catholic doctrine toward usury. See Noonan, Tokos and Atokion: An Examination of Natural Law Reasoning Against Usury and Against Contraception, 10 Natural L. Forum 215 (1965). See also P. Selznick, Law, Society and Industrial Justice 26, 251-52, where due process is described as a principle. Selznick has said that "[a] principle generates rules of law, as circumstances may require or permit. Principles are legal instruments for devising rules and for criticizing them." $I d$. at 252 . The best-interests principle might serve to generate an evaluative 
nineteenth century, adjudication of a custody dispute between a husband and wife was controlled by a simple rule: the father, in Lord Ellenborough's words, was "the person entitled by law to the custody of his child." ${ }^{32}$ Deciding any custody dispute under these standards required a single factual determination: whether one of the claimants was the biological father of the child who was born while that claimant was married to the child's mother. ${ }^{33}$

An absolute rule of paternal preference does not appear to have been generally applied in nineteenth-century America, and in many jurisdictions courts were authorized to award custody to either parent as part of a divorce proceeding. ${ }^{34}$ While some statutes expressed a preference for the father, it appears a rule based on fault emerged: "The children will be best taken care of and instructed by the innocent party." 35 This standard was not as openended as first appears because divorce in the nineteenth century required a showing of fault on the part of a spouse. ${ }^{36}$ Particularly given the social con-

or intermediate set of rules, but the failure of the courts to use the principle for this purpose is a primary concern of this article.

32. King v. DeManneville, 102 Eng. Rep. 1054,1055 (K.B. 1804).

33. The force of these rules is illustrated by an early habeas corpus case where a mother's custody claims against an estranged husband were denied even though the child was young, the separation had been forced by the father's ill-treatment of the mother, and there were uncontested allegations of continuing misconduct by the father. King v. DeManneville, 102 Eng. Rep. 1054 (K.B. 1804). Similarly, neither a husband's "cruelty" and "brutality" to his wife nor his cohabitation with another woman after desertion would justify a court of law giving custody to his wife even though he was at the time apparently in jail, where the child was brought to him every day. Ex parte Skinner, 27 REv. R. 710,713 (C.P. 1824). See also King v. Greenhill, 111 Eng. Rep. 922 (K.B. 1836).

Early English custody cases suggest that the settlement of such private disputes over custody was kept separate from the child-protection function. The courts of equity and the Chancellor -but not the law courts-were seen as having the power to control an abusive father's legal right to custody or, in an appropriate case, appoint someone else as guardian, if that were necessary to protect the child. See Shelley v. Westbrooke, 37 Eng. Rep. 850 (Ch. 1817). The Chancellor could also enjoin the husband's removal of the child from the Kingdom. See DeManneville v. DeManneville, 32 Eng. Rep. 762 (Ch. 1804). But no discretionary power appears to have existed in courts of law to adjudicate a custody dispute in favor of a wife as against her husband.

34. Earlier statutes in several states expressly authorized courts to make temporary and permanent custody orders as part of divorce proceedings. See, e.g., An Act Concerning the Custody of Children, ch. 221, $\S \S 1-2$, [1815] Laws of New York 225; $c f$. Cole v. Cole, 23 Iowa 433, 446 (1867). See generally J: Bishop, Commentaries on the Law of Marriage and Divorce 518 (1852). Many early cases demonstrate that the mother as well as the father could claim custody, see, e.g., Cole v. Cole, 23 Iowa 433, 446 (1867); Cook v. Cook, I Barb. Ch. 639 (N.Y. 1846); Bascom v. Bascom, Wright 632 (Ohio 1834); and that the father's claim should yield to the good of the child. See, e.g., Cole v. Cole, 23 lowa 433, 446 (1867); People ex rel. Barry v. Mercein, 8 Paige 46, 69 (N.Y. Ch. 1839); McKim v. McKim, 12 R.1. 462, 464, 34 Am. R. 694 (1879). See generally J. Bishop, supra at 520; A. Lloyd, LAW of Divorce 241 (1887). In 1839, the English Parliament modified the absolute rule of paternal preference for legitimate children by passing the socalled Talfourd's Act, which gave a mother the right to custody of infants under the age of seven years, An Act to Amend the Law Relating to the Custody of Infants, 2 \& 3 Vict., c. 54 (1839); and later for infants of any age. An Act to Amend the Law as to the Custody of lnfants, $36 \& 37$ Vict., c. $12(1873)$.

35. J. BisHoP, supra note 34, at 520. Cf. Barrere v. Barrere, 4 Johns Ch. 187 (N.Y. 1819); Cole v. Cole, 23 lowa 433, 447 (1867).

36. See A. Lloyd, supra note 34 , at $3,40-145$. 
vention that the wife filed for divorce, courts no doubt awarded custody to the mother more frequently than to the father. ${ }^{37}$

Gradually, in the twentieth century, courts came to acknowledge formally what had perhaps long been the reality. ${ }^{38}$ The statutory language, by now putting the wife on an equal footing with the husband, came to be interpreted as giving a substantial preference to the mother, particularly if the children were young. In the words of a New York appellate court, "the child at tender age is entitled to have such care, love, and discipline as only a good and devoted mother can usually give." 39 This maternal-preference rule was achieved in various ways: sometimes by statute, ${ }^{40}$ often by a judicially constructed rule that it was in the best interests of the child "of tender years" for the mother-unless shown to be unfit-to have custody. ${ }^{41}$

At the present time, maternal-preference standards are being displaced by a formal insistence on a neutral application of the best-interests standard. A number of states have amended their statutes expressly to provide no presumption in favor of either parent in applying the best-interests principle, ${ }^{42}$ and only a few states now still have maternal preference by statute. ${ }^{43}$ No-fault

$\overline{3} \overline{7}$. One commentator, writing in 1887 , described the supposed paternal preference as a "fiction." Id. at 242. Cf. Comment, The Custody of Children, 2 IND. L.J. 325, 326 (1926).

38. See generally Comment, supra note 37.

39. Ullman v. Ullman, 151 App. Div. 419, 424-25, 135 N.Y.S. 1080, 1083 (1912).

40. See, e.g., OkLa. Stat. Ann. tit. 30, § 11 (1955); S.D. Comp. Laws Ann. \$ 30-27-19(2) (1967); Utah Code ANN. \$ 30-3-10 (Supp. 1973).

4l. See, e.g., Schildgen v. Schildgen, 260 Iowa 110, 148 N.W.2d 629 (1967); Clark v. Clark, 298 Ky. 18, 181 S.W.2d 397 (Ct. App. 1944); West v. West, 170 So. 2d 160 (La. App. 1964); Reiland v. Reiland, 280 Minn. 564,160 N.W.2d 30 (1968); McDermott v. McDermott, 192 Minn. 32, 255 N.W. 247 (1934); Hansen v. Hansen, 43 Wash. 2d 520, 262 P.2d 184 (1950); Farwell v. Farwell, 33 Wis. 2d 324, 147 N.W.2d 289 (1967). The parental-fitness test over time became ever more elastic, even to the point where it often seemed indistinguishable from the best-interest standard. For example, some courts analyzed a contest between two parents in terms of relative fitness. See, e.g., Deyette v. Deyette, 92 Vt. 305, 309, 104 A. 232, 234 (1918) ("The good of the child is the primary consideration, and that can be judged to some extent by the comparative acts of the father and the mother ....); $c f$. Stinson v. Meegan, 318 Mass. 459, 462-63, 62 N.E.2d 113, 115 (1945):

[C]ustody would be granted [to a maternal aunt] as against the claim of the surviving [father] only if he were found to be "unfit to have such custody," . . but it is settled that the meaning of "unfit" is not confined to the moral character or personal qualities of the parent, and that it embraces other circumstances . . particularly such circumstances as involve the welfare of the child himself.

42. See, e.g., Cal. Civ. Code $\S 4600$ (West Supp. 1975) (amended in 1970); Fla. Stat. ANi. $\S$ 61.13(2) (Supp. 1975) (amended in 1971); Neb. Rev. Stat. \& 42-364(2) (Cum. Supp. 1974) (amended in 1974); Ore. Rev. Stat. § 107.105(1)(a) (1974) (amended in 1971). These changes were enacted in the face of proffered justifications for maternal preference by scholarly commentators. See, e.g., Watson, supra note 5, at 82, suggesting a presumption in favor of mother for children under ten years of age and for all female children; and R. Levy, supra note 4, at 224: "The Uniform Marriage and Divorce Act should contain a presumption that the mother is the appropriate custodian-at least in young children, and probably for children of any age."

43. Utah has a presumption in favor of the mother in the case of younger children. UTAH Code ANn. \& 30-3-10 (Supp. 1975). Oklahoma and South Dakota provide for the best-interests test with the following proviso: 
divorce, the changing social conception of appropriate sex roles, and the women's movement all are contributing to this trend. ${ }^{44}$

Divorce custody standards now show the overwhelming dominance of the best-interests principle. A majority of the states provide by statute for a bestinterests-of-the-child standard. ${ }^{45}$ Other states have no statutory standard but

\begin{abstract}
As between parents adversely claiming the custody or guardianship, neither parent is entitled to it as of right, but, other things being equal, if the child is of tender years, it should be given to the mother; if it be of an age to require education and preparation for labor or business, then to the father.

Okla. Stat. Anv. tit. 30, § 11 (1955); S.D. Comp. Laws Ann. § 30-27-19(2) (1967).
\end{abstract}

44. For documentation of the changing work roles of women as evidenced by the continuing increase of mothers in the labor force, see Waldman \& Whitmore, Children of Working Mothers, March 1973, 97 Monthly Lab. Rev. May 1974, at 50. For various perspectives on changes in sex roles and the effects of the women's movement, see generally W. Chafe, The American Woman: Her Changing Social, Economic, and Political Roles, 1920-1970 (1972); Corporate Lib: Women's Challenge to Management (E. Ginzberg \& A. Yohalem eds. 1973); The Future of the Family (L. Howe ed. 1972); Women: Their Changing Roles (E. Janeway ed. 1973); New York City Commission on Human Rights, Women's Role in Contemporary Society (1972); Sex Roles in a Changing Society (G. Seward \& R. Williamson eds. 1972); The Women's Movement: Social and Psychological Perspectives (H. Wortis \& C. Rabinowitz eds. 1972).

45. Thirty-one states appear to have statutes that provide for the best-interests-of-the-child test in some form. These statutes vary considerably. Some specify factors that may be considered in applying the standard, such as sex, age, or preference of the child. A few contain presumptions or preferences based on the sex of the parent. Others combine best-interests with vestiges of a parental-fault standard.

Statutes without specification: Ill. ANs. STAT. ch. 40, $\$ 19$ (Smith-Hurd Supp. 1974) ("proper and for benefit of the child"); Mass. Axw. Laws ch. 208, $\S 28,31$ (1958) ("happiness and welfare of the children"; "benefit of the children"); Nev. REv. STAT. \& 125.140(1) (1973) ("most expedient under all the circumstances, and most for the present comfort and future well-being of such children"); N.H. Rev. STAT. ANN. $\$ 458: 17$ (1968) ("most conducive to [the child's] benefit"); N.Y. DOM. REL. LAW $\$ 240$ (McKinney 1964) ("having regard to the circumstances of the case and of the respective parties and to the best interests of the child"); N.C. Gen. STAT. \$ 50-13.2(a) (Supp. 1974) ("best promote the interests and welfare of the child"); TENx. Code ANN. \$36-828 (Supp. 1974) ("as the welfare and interest of the child ... demand"); TEx. FAm. Code $\$ \S 3.55,14.01$ (1973) ("in the best interest of the child"); Wyo. STAT. ANN. \& 20-61 (1959) ("most expedient under all the circumstances, and most for the present comfort and future well-being of the child").

Statutes that specify factors that may be considered: Alaska STat. \$ 09.55.205(1) (1973); Ariz. Rev. Stat. AnN. \$ 25-332(a) (Supp. 1973); Colo. Rev. Stat. AnN. § 14-10-124 (1974); Conn. Gen. Stat. Rev. § 46-42 (1975); Fla. Stat. Ans. \$61.13(3) (1975 West Fla. Sess. Laws No. 2, at 183); Hawali Rev. Stat. §571-46 (1968); Ind. Code § 31-1-11.5-21(a) (1974); Ky. Rev. Stat. AnN. \$ 403.270 (1973); Minn. Stat. Ann. \$ 518.17 (Supp. 1975); Mo. Ann. Stat. \$ 452.375 (Vernon Supp. 1975); Neb. Rev. Stat. \$ 42-364 (Supp. 1974); N.J. Stat. AnN. § 9:2-4 (Supp. 1975); Oho Rev. Code Anv. \$ 3109.04 (Page Supp. 1974); S.C. Code Ann. \$ 20-115 (1962); Wash. Rev. Code ANN. $\$ 26.09 .190$ (Supp. 1974)

Preference or presumption based on sex of parent: OKLa. STat. ANs. tit. 30, § 11 (1955); S.D. Comp. Laws Ann. \$ 30-27-19 (1967); Utah Code Ann. § 30-3-10 (Supp. 1973).

Best-interests plus parental fault: GA. CoDE ANN. $\S \S 30-127$ (1969), 74-107 (1973) (party not at fault entitled to custody, but court "in the exercise of a sound discretion" should look to and "determine solely what is for the best interest of the child"); La. Civ. Cone art. 157 (West Supp. 1975) (child shall be placed with party obtaining separation or divorce "unless the judge shall, for the greater advantage of the children," order otherwise); Ore. Rev. STAT. $\$ 107.105$ (1)(a) (1973) ("the court shall consider the best interests of the child and the past conduct and demonstrated moral standards of each of the parties"); UTAн CODE AN. \& 30-3-10 (Supp. 1973) ("the court 
have relied on their courts to develop a best-interests standard. ${ }^{46}$ Most of the remaining states have broad and vague statutory standards-calling for determination by such principles as "right and proper," "expedient," or "just and reasonable"-that have been judicially construed as involving the bestinterests inquiry. ${ }^{47} \mathrm{~A}$ number of statutes express statutory preferences for biological parents over third parties ${ }^{48}$ or provide for the application of the best-interests standard only in choosing between parents. ${ }^{49}$ But many specifically provide for awards to nonparents without any finding of parental unfitness if in the child's best interests ${ }^{50}$ or in the court's discretion. ${ }^{51}$

\section{Guardianship Custody Law}

The appointment of a guardian of a child's person (personal guardian) is normally made by a probate court. ${ }^{52}$ While there are different types of guardians $^{53}$ and the term is used to describe very different sorts of rela-

shall consider the best interests of the child and the past conduct and demonstrated moral standards of each of the parties").

46. See, e.g., D.C. Code Axx. \$§ 11-1101(1) (1973), 16-911(4) (1966), and Dorsett v. Dorsett, 281 A.2d 290 (D.C. App. 1971); Kan. Stat. ANw. $\$ 60-1610($ a) (Supp. 1974), and Moudy v. Moudy, 211 Kan. 213, 505 P.2d 764 (1973); MD. Ann. Code art. 16, §§ 25 (Supp. 1974), and Chilenni v. Chilenni, $197 \mathrm{Md} .257,78$ A.2d 750 (Ct. App. 1951); PA. Stat. Ann. tit. 23, §§ 15(1)(b), (2)(b) (Supp. 1975), and Commonwealth ex rel. Mann v. Mann, 181 Pa. Super. 438, 441, 124 A.2d 432, 433 (1956) (dictum); R.I. GeN. Laws ANN. § 15-5-16 (1956), and Kelley v. Kelley, 77 R.I. 229, 230, 74 A.2d 452, 453 (1950) (dictum); VT. Stat. Ann. tit. 15, $\$ 557$ (1974), and Deyette v. Deyette, 92 Vt. 305, 104 A. 232 (1918) ("good of the child"). See also ME. Rev. Stat. AnN. tit. $19, \S 752$ (1964).

47. See, e.g., Ala. Code tit. 34, $\$ 35$ (1958) ("give the custody . . to either father or mother, as may seem right and proper, having regard to the moral character and prudence of the parents [and] the age and sex of the children"), and Hougesen v. Hougesen, 271 Ala. 452, 124 So. 2d 438 (1960) (supreme concern is best interests of child); Mıch. Comp. LAws ANx. $\$ 552.16$ (1967) ("just and proper"), and Kane v. Kane, 241 Mich. 96, 99, 216 N.W. 437, 438 (1927) ("a child of divorced parents is a ward of the court" and in determining custody and care, "the paramount consideration shall be its welfare"); N.M. STAT. ANs. \& 22-7-6 (Supp. 1973) ("just and proper"), and Urzua v. Urzua, 67 N.M. 304, 355 P.2d 123 (1960) (welfare-of-the-child test); W. VA. Code ANs. \$ 48-2-15 (Supp. 1974) ("expedient"), and Smith v. Smith, 138 W. Va. 388, 76 S.E.2d 253 (1953) (welfare-of-the-minor test); WIS. STAT. ANN. \$247.24 (Supp. 1975) ("just and reasonable"), and Larson v. Larson, 30 Wis. 2d 291, 140 N.W.2d 230 (1966) (best-interests-of-the-child test).

48. See, e.g., Cal. Civ. Code $\$ 4600$ (West Supp. 1975); Kan. Stat. Ann. \$ 60-1610 (Supp. 1974) (parents must be found unfit); Wis. STAT. ANs. $\$ 247-24$ (Supp. 1975) (parents must be found unfit).

49. See, e.g., La. Civ. Code art. 157 (West Supp. 1975); Minn. Stat. AnN. \$ 518.17 (Supp. 1975).

50. See, e.g., Conn. Gen. Stat. Rev. § 46-42 (1975); Mass. ANN. Laws ch. 208, § 28 (1958); Neb. Rev. Stat. \& 42-364 (Cum. Supp. 1974); N.C. Gen. Stat. §50-13.2 (Supp. 1974); Tenn. Code ANn. \$ 36-828 (Supp. 1974).

51. See Me. Rev. Stat. ANn. tit. 19, § 752 (1964).

52. See, e.g., Ohio Rev. Code. Ann. \$ $2101.24(\mathrm{D})$ (Page 1968); Mass. Gen. Laws Ann. ch. 201. $\S 1$ (Supp. 1975).

53. There are, for example, guardians ad litem, with responsibility for representation in court, and guardians of a child's property, necessary when a child inherits property. A child's biological parents are considered the "natural" guardians of his person, but court appointment has long been thought necessary for guardianship of a child's property. See $1 \mathrm{~W}$. BLAckstone, 
tionships, ${ }^{54}$ a personal guardian basically has the exclusive right to decide where the child lives, can control and discipline the child, has the power to consent to the child's medical care, but has no duty to support a child. ${ }^{55}$

Guardianship proceedings typically arise when neither of a child's parents is alive or available and a nonparent wishes to have custodial rights. Most guardianship appointments are probably uncontested, but when there are competing claimants, the dispute is governed by guardianship law. Sometimes a natural parent can be involved in such disputes. This may occur after the death of the parent who has had custody following a divorce. If the child's stepparent (i.e., the spouse of the deceased parent) or some other relative of the deceased parent wishes to become the child's legal guardian, the noncustodial natural parent may object. ${ }^{56}$ Sometimes guardianship proceedings are initiated by a noncustodial spouse who wishes appointment to defeat an earlier divorce custody decision. " Occasionally, after a neglected child has been placed in foster care by a juvenile court, the foster parents will seek appointment as the guardian. ${ }^{58} \mathrm{~A}$ guardianship custody dispute nearly always involves the private-dispute-settlement function, for there are competing private litigants; but it may involve the child-protection function as well if the court must evaluate a claim that one of the claimants will endanger the child.

With guardianship laws, as with divorce custody, contemporary legal standards reveal considerable judicial discretion and less automatic deference paid

Commertaries *453. Although now obsolete, there were several other types of feudal guardianships: e.g., guardianship in socage; guardianship by nurture and guardianship in chivalry. See R.

Tyler. Commentaries ON THE LAW OF INFANCY $237-47$ (1868).

54. See C. Foote, R. Levy, \& F. Sander, Cases and Materials on Family law 374 (1966).

55. The Model Probate Code described the duties of a child's personal guardian as follows: It is the duty of the guardian of the person to care for and maintain the ward and, if he is a minor, to see that he is properly trained and educated and that he has the opportunity to learn a trade, occupation or profession. . .

The guardian of the person shall be entitled to the custody of the ward ....

Model Probate Code $\$ \S 219.220$ (1946).

Guardians, unlike natural parents, lack the power to consent to adoption, and they often have less power to control visitation and to consent to medical treatment. Although many state statutes call for judicial regulation and control of personal guardians, see, e.g., Cal. Prob. Code $\$ 1400$ (West Supp. 1975); following the initial appointment, there is, typically, no court supervision whatsoever, unless someone complains. See l. Weissmax. Guardianship, A Way of Fulfilling Public Responsibility for Children 101-02 (1949).

56. See, e.g., In re Stuart, 280 N.Y. 245, 20 N.E.2d 741 (1939) (stepparent against noncustodial parent); In re Bock, 280 N.Y. 349. 21 N.E.2d 186 (1939) (brother of deceased father against noncustodial mother).

57. See, e.g., Greene v. Superior Court, 37 Cal, 2d 307, 231 P.2d 821 (1951) (mother's petition for guardianship appointment in order to avoid constraints of divorce decree denied due to lack of jurisdiction).

58. See, e.g., In re B.G., 11 Cal. 3d 679, 686 n.7, 523 P.2d 244, 248 n.7, 114 Cal. Rptr. 444. 448 n.7 (1974) (indication in juvenile court proceeding that petition for guardianship had been filed). See also Taylor, Guardianship or "Permanent Placement" of Children, 54 CAL. L. Rev. 741, 744 (1966), where the author recommends that such petitions by foster parents be encouraged. 
to the claims of natural parents. The best-interests-of-the-child principle is clearly of primary importance in resolving guardianship disputes arising after the death of both parents. Today, every state provides by statute that the last surviving parent may nominate by will a personal guardian for a minor child, subject to confirmation by the court. ${ }^{59}$ Unlike the nineteenth century, however, when courts considered themselves bound to confirm a "qualified" parental nomination, ${ }^{60}$ the law in most jurisdictions today permits the court to appoint some other person if the welfare of the child would thereby be better served. ${ }^{61}$

Generalization is more difficult where a natural parent is available and objects to the appointment of a nonparent, but a trend towards more discretionary standards seems discernible. In nineteenth century England, absent a showing of substantial abuse or neglect, ${ }^{62}$ a father's guardianship of his legitimate children was "in no degree dependent on the discretion of chancellors or judges." ${ }^{3}$ Today, it is still unusual for a court to appoint a nonparent guardian for a child over the objection of a parent who then has custody, ${ }^{64}$

59. See, e.g., Cal. Prob. Code $\S 1403$ (West 1956); Mass. Ann. Laws ch. 201, § 3 (1969); N.J. STAT. ANN, tit. 3A, $\$$ 6-18 to 23 (1953).

60. See, e.g., In re McCoun, 96 Kan. 314, 150 P. 516 (1915); Stone v. Dorselt, 18 Tex. 700 (1857). See also W. Macpherson, A Treatise on the Law Relating to Infants 90 (1841); J. Woerner, The American Law of Guardianship 55-62 (1897). During the reign of Charles II, a statute was passed giving the father the power by will to designate the child's guardian after his death. Tenure's Abolition Act, 12 Car. 2, c. 24, $\$ 8$ (1660). In England, until 1886, when the Guardianship of Infants Act, 49 \& 50 Vict., c. $27, \S 3$ (1886), was passed, the child's mother was disabled from appointing a testamentary guardian herself. See Ex parte Edwards, 26 Eng. Rep. 1099 (1747); Villareal v. Mellish, 36 Eng. Rep. 719, 721 (1737) (dictum). Indeed, the father might, by the appointment of a testamentary guardian, deprive the mother of custody after his death. See Talbot v. Shrewsbury, 41 Eng. Rep. 259, 263 (1840). Some American state courts followed this harsh rule, see, e.g., In re Van Houten, 2 N.J. Eq. 220, 226, 39 Am. Dec. 707 (1835), or followed the English example by not allowing the mother to appoint a testamentary guardian, see, e.g. . Ingalls v. Campbell, 18 Ore. 461, 464-70 (1889). The more common legislative pattern was to grant the testamentary appointment power to the mother if she was the surviving parent; see, e.g., An Act Relating to Wills, Act of May 3, 1852, § 72, 50 Ohio Laws 310; or to condition the father's power on the consent of the mother. See, e.g., ch. 51, \& 1, [1871] N.J. Law's 23-24. See also J. WOERner, supra at 59-60.

61. See, e.g., In re Walsh's Estate, 100 Cal. App. 2d 194, 223 P.2d 322 (1950); Comerford v. Cherry, 100 So. 2d 385 (Fla. 1958). See generally Annot., 67 A.L.R.2d 803, 810 (1959) and cases cited therein.

62. See J. Woerner, supra note 60, at 90; cf. Ramsay v. Ramsay, 20 Wis. 533 (1866).

63. R. Tyler, supra note 53, at 245. See also Ex parte Hopkins, 24 Eng. Rep. 1009 (1732), J. WOERNER, supra note 60, at 53-55.

64. Statutes in nearly every state provide that a minor who is fourteen years of age or older can nominate his or her own guardian. See, e.g., Mich. Comp. LAws Axi. $\$ 703.3$ (1968). A court is usually bound to appoint the juvenile's own nominee so long as that person is "fit" or "suitable." See, e.g., In re Howard, 66 N.M. 445, 349 P.2d 547 (1962). See generally Annot., 85 A.L.R.2d $92 \mathrm{l}$ (1962). In In re Kentera, 41 Cal. 2d 639, 262 P.2d 317 (1953), a minor attempted to appoint his paternal grandmother over the objection of the custodial mother. The court held that before a minor's petition could be granted, the statute required a finding of necessity and convenience: "The statutory provisions were not intended to upset the normal relationship of parent and child or to disrupt normal family discipline by allowing the 14-year-old minor to withdraw from the family circle at his whim." Id. at $643,262 \mathrm{~A} .2 \mathrm{~d}$ at 319. 
and some states have a presumption in favor of a natural parent. ${ }^{65}$ Where a stepparent, foster parent, or relative with whom a child has lived wishes to be appointed guardian, however, courts have used the best-interests principle to deny the competing claims of a noncustodial parent who wishes to regain custody. ${ }^{66}$

\section{Juvenile Court Child-Neglect Laws}

The power of government to protect children by removing them from parental custody has roots deep in American history. By the early nineteenth century, the parens patriae power of the state was thought sufficient to empower courts of equity to remove a child from parental custody and appoint a suitable person to act as guardian. ${ }^{67}$

Every state today has a statute allowing a court, typically a juvenile court, to assume jurisdiction over a neglected or abused child and to remove the child from parental custody under broad and vague standards ${ }^{68}$ reminiscent

65. See, e.g., In re Marino, 30 Cal. App. 3d 952, 106 Cal. Rptr. 655 (1973) (finding of detriment necessary before custody can be denied nonconsenting parent); Forrester v. Livingston, 216 Ga. 798, 120 S.E.2d 174 (1961) (parent has right to custody as against statutory guardian if fit or competent); Melroy v. Keiser, 123 Kan. 513, 255 P. 978 (1927) (parent is entitled to custody where he has not legally surrendered his right to custody and has not been adjudged unsuitable); Ex parte Bryant, 106 Ore. 359, 210 P. 454 (1922) (court unjustified in denying custody to parent except in cases of extreme misconduct).

66. See, e.g., In re Stuart, 280 N.Y. 245, 20 N.E.2d 741 (1939); In re Bock, 280 N.Y. 349,21 N.E.2d 186 (1939).

67. [A]lthough, in general, parents are intrusted with the custody of the persons, and the education of their children, yet this is done upon the natural presumption, that the children will be properly taken care of, and will be brought up with a due education in literature, and morals, and religion; and that they will be treated with kindness and affection. But, whenever this presumption is removed; whenever (for example) it is found, that a father is guilty of gross ill treatment or cruelty towards his infant children; or that he is in constant habits of drunkenness and blasphemy, or low and gross debauchery; or that he professes atheistical or irreligious principles; or that his domestic associations are such as tend to the corruption and contamination of his children; or that he otherwise acts in a manner injurious to the morals or interests of his children; in every such case, the Court of Chancery will interfere, and deprive him of the custody of his children, and appoint a suitable person to act as guardian, and to take care of them, and to superintend their education.

2 J. Story, Commentaries on Equity Jurisprudence 702 (7th ed. 1857) (footnotes omitted). Much earlier, seventeenth-century laws of Massachusetts, Connecticut, and Virginia specifically authorized magistrates to "bind out" or indenture children of the poor over parental objections. See 1 Children and Youth in America 64-70 (R. Bremner ed. 1970). Although it is unclear how frequently this power was exercised, the records of Watertown, Massachusetts, for instance, show that in 1671, Edward Sanderson's two oldest children were bound out as apprentices "where they may be educated and brought up in the knowledge of God and some honest calling." The reason given: poverty. Id. at 68. For a discussion of the history of child-neglect laws, see Thomas, Child Abuse and Neglect, Part I: Historical Overview, Legal Matrix, and Social Perspectives, 50 N.C.L. REv. 293 (1972). For a historical description of how neglected children were cared for, see generally, H. Folks, The Care of Destitute, Neglected, and Delinquent Children (1902).

68. Most states provide several grounds for assuming jurisdiction, such as parental abuse, see e.g., Colo. Rev. Stat. ANs. \$ 19-1-103(20)(a) (1974); "an environment injurious to the child's welfare," see, e.g., Fla. Stat. Ann. § 39.02(1) (1975); "or a child in danger of being brought up 
of those invoked by courts of equity in the nineteenth century. A complex social welfare bureaucracy, however, now is responsible for discovering children in need of protection and initiating appropriate judicial action. A case usually reaches juvenile court only after weaving its way through a process where numerous officials-including social workers, probation officers, and court personnel-may have had contact with the family. ${ }^{69}$ The judicial inquiry itself usually contains two stages: first, the court must determine whether it has jurisdiction over the child; if so, the second stage involves a dispositional hearing, where the judge decides the manner of intervention. The court may leave the child at home and require supervision of the home, psychological counseling for the family, or both. But often the court will remove the child from parental custody, ${ }^{70}$ subject to some court review of the family situation at a later date. ${ }^{71}$

If the court removes the child from parental custody, it normally orders that the care and custody of the child be supervised by the welfare or probation department, which, in turn, will place the child with relatives, foster parents, or in an institution. ${ }^{72}$ Placement does not extinguish the natural parent's

to lead an idle, dissolute or immoral life," see, e.g., Wash. Rev. Code Ann. \$ 13.04.010(2) (1962). See generally S. Katz, When Parents Fail: The Law's Response to Family Breakdown 83-85 (1971). Every state, except perhaps Maine and West Virginia, include in their jurisdictional statute at least one extremely vague and broad provision, allowing jurisdiction over a child who is not receiving "proper" care or attention. For an excellent general discussion of the inadequacies of present-day neglect laws, see Wald, supra note 4. For a digest and compilation of state child neglect statutes, see Katz, Howe, \& McGrath, Child Neglect Laws in America, 9 FAmily L.Q. I (1975).

69. Unfortunately, very little is known about how the discretion of these various officials is exercised. See J. Pers, Somebody Else's Children: A Report on the Foster Care System in California, September 1, 1974 (unpublished manuscript on file at Institute of Governmental Studies, University of California, Berkeley). The process is usually triggered by a report from a social worker or the police, or less frequently from a neighbor, relation, medical professional, or school staff member.

Although practices vary, a member of some special unit of the social welfare or probation department is usually responsible for an initial investigation of the report. Customarily, this investigation is not extensive; often, it will involve only a single visit to the home and a telephone conversation with the person who turned in the report. The investigator, sometimes together with a supervisor, then must decide whether to close the case, or to suggest that the welfare agency informally, and noncoercively, provide services or supervision, or to file a petition in court. At this point in the process, some parents voluntarily agree to the child's removal from their custody and placement in a foster home occurs without a court proceeding being necessary. However, in some of these placements, a significant degree of state coercion is involved; and in some cases, parents' "consent" is hardly voluntary when judged by standards applicable in other areas of the law. See Mnookin, supra note 4, at 600-01.

70. See Mnookin, supra note 4 , at 606.

71. See, e.g., Cal. Welf. \& INST'vs Code $\S 828,729$ (West 1972) (requiring a report and review at least once every twelve months).

72. See Mnookin, supra note 4, at 609-10; J. Pers, supra note 69. No national data is available, but it appears that children are removed from parental custody in a significant percentage of the cases heard in juvenile court. In 1972, for example, the Los Angeles juvenile courts ordered removal in 62 per cent $(1,028$ out of 1,656) of the cases. Letter from Los Angeles County Department of Public Social Services, September 25, 1973 
duty to support the child financially, ${ }^{73}$ although ordinarily the state and the federal governments bear the cost because most affected families are very poor. ${ }^{74}$ The state agency and ultimately the court-not the foster parentsare responsible for deciding where the child will live. ${ }^{75}$

This process can generate a variety of custody disputes. The natural parent may object to the initial attempt to remove the child. ${ }^{76}$ After removal, the natural parent may seek the return of the child, and the social welfare department ${ }^{77}$ or foster parents ${ }^{78}$ may object. The foster parents may also object to the transfer of the child to some other foster home. ${ }^{79}$ For all of these sorts of disputes, the law of juvenile neglect provides the principle framework for resolution. Initially, most juvenile court neglect proceedings involve the child-protection function, for usually an agency of the state is asking a juvenile court to deny custody to a child's parent or parents on the basis of abuse or neglect that is thought to require state intervention in order to protect the child; but some juvenile court proceedings may involve the privatedispute-settlement function as well, for there may be competing private claimants.

In neglect cases, juvenile courts today use highly individualized, discretionary standards to decide whether a child should be removed from parental

In San Francisco during the same year, the figure was 65 per cent (262 out of 402) of the cases where it assumed jurisdiction. 1972 San Francisco Juv. Ct. Ann. Rep. (unpublished). Although some of these children were placed with relatives, over 80 per cent of those removed were placed in foster care. Similarly, a study of dispositions in New York State during the years 1957-60 showed that the probability of removal from the home was as great as that of supervision by the probation department-each accounted for slightly over 30 per cent of the neglect petitions adjudicated by the court. See N.Y. Jonnt Legislative Comm. on Court Reorganization, The Family Court ACT: RePort No. 2 (1962). More recently, a study conducted in 1968-69 found that in New York, the child was taken from its home in over half of the cases of abuse or neglect adjudicated. See Note, An Appraisal of New York's Statutory Response to the Problem of Child Abuse, 7 Colum. J. Law \& Soc. Рrob. 51, 72 (1971).

73. See, e.g., CAL. Welf. \& INst'Ns Code $\$ 903$ (West 1972). The natural parents are normally allowed to visit their child and to consent to medical treatment, although either right can be limited by the court. See id. $\S$ 737, 739(a) (West Supp. 1975).

74. See S. Jenkins \& E. Norman, Filial Deprivation and Foster Care 2, 25-30 (1972); Rein, Nutt, \& Weiss, Foster Family Care: Myth and Reality, in ChILdRen and Decent People 24 (A. Schorr ed. 1974). For a careful analysis of how the judicial system treats custody decisions for the poor, see Kay \& Phillips, Poverty and the Law of Child Custody, 54 Calif. L. Rev. 717 (1966). See also Childhood \& Government Project, Finance of Foster Care, 1974 (unpublished manuscript on file at School of Law, University of California, Berkeley), ten Broek, California's Dual System of Family Law: Its Origin, Development, and Present Status pt. 1, 16 STAN. L. Rev. 257 (1964); pt. 2, 16 STAN. L. Rev. 900 (1964); pt. 3, 17 Stan. L. Rev. 614 (1965).

75. See Note, The Rights of Foster Parents to the Children in Their Care, 50 CHI.-KENT L. REv. 86, $96-99$ (1973). A good example of a court refusing to consider the wishes of foster parents as to the child's future placement is contained in In re Jewish Child Care Ass'n, 5 N.Y.2d 222, 156 N.E. 700,183 N.Y.S.2d 65 (1959).

76. See, e.g., In re S, 31 Cal. App. 3d 112, 107 Cal. Rptr. 62 (1973).

77. See, e.g., In re Francecisco, 16 Cal. App. 3d 310,94 Cal. Rptr. 186 (1971).

78. See, e.g., In re B.G., 11 Cal. 3d 679, 523 P.2d 244, 114 Cal. Rptr. 444 (1974).

79. See, e.g., In re Jewish Child Care Ass'n, 5 N.Y.2d 222, 156 N.E.2d 700, 183 N.Y.S.2d 65 (1959). 
custody. The decision is made in the disposition stage of the proceeding, ${ }^{80}$ where the use of the best-interests standard is extremely widespread. ${ }^{81} \mathrm{~A}$ number of states, either in the purpose clauses of their juvenile court acts or in their case law, express a preference for strengthening the natural family ${ }^{82}$ and leaving the child in his own home unless his welfare is endangered. ${ }^{83}$

80. It might be thought that the statutory standards determining when a juvenile court should assume jurisdiction are sufficiently stringent to exclude all but the most extreme cases from the dispositional phase of any juvenile court proceeding. But the jurisdictional phase of the courts proceeding provides no such safeguard. See Wald, supra note 4, at 1000 . Indeed, some state courts now appear to use the best-interest standards in determining not only disposition, but also jurisdiction itself. See Mnookin, supra note 4, at 614. More generally, the jurisdictional standard is the same whether a court is going merely to supervise the child within the home or to remove the child. Consequently, to assume jurisdiction in itself is not seen as a particularly important decision. Interviews and courtroom observation alike suggest that the judge and social worker consider the dispositional decision the key issue. This conclusion is supported by data showing that the juvenile court assumes jurisdiction in a very high percentage of cases where there is a hearing. See id. at 606 .

81. Twenty-three states have statutory dispositional standards that refer to "the bestinterests-of-the-child," "welfare of the child," or placement "best suited to protect the welfare of the child." Ala. Code tit. 13, \$361 (1958); Cal. Welf. \& Insr'ns Code 726(c) (West 1972) (welfare of minor requires removal); Colo. Rev. Stat. ANx. $\$ 22-1-9(3)$ (1974); D.C. Code ANN. \$16-2320(a) (1973); Ga. Code Ann. \$ 24A-230l(a) (Supp. 1974); Hawait Rev. Stat. \$ 571-48(6) (1968); Ind. Code \$ 31-5-15(5) (1973); Md. Ann. Code \$ 3-831(3) (1974); Mass. Ann. Laws ch. 119, § 26 (1975); Miss. Code Ann. \$ 43-21-19 (1972); Mont. Rev. Codes Ann. \$ 10-1310(10)(f) (Supp. 1974); N.M. Stat. Ann. § 13-14-31 (Supp. 1973); N.C. Gen. Stat. § 7 A-286 (Supp. 1974); N.D. Cent. Code $\S 26-20-30$ (1974); OkLA. Stat. Ann. tit. 10, $\$ 1115(a), 1116(a)(1)$ (Supp. 1974) (best serving the interests of the child and the public; consistent with the welfare of the child); Ore. Rev. Stat. \$ 419.507 (1974); Pa. Stat. Ann. tit. 11, § 50-32l(a) (Supp. 1975); R.I. GeN. Laws ANN. § 14-1-34 (Supp. 1974); TeNs. Code ANN. \$ 37-230(a) (Supp. 1974); Tex. Fam. Code \& 14.01, 14.07 (1975); Vt. Stat. Ann. tit. 33, \& 656(a) (Supp. 1975); W. VA. Code AnN. § 49-6-5 (Supp. 1975); Wro. Stat. Ann. \& 14-115.30 (Supp. 1975).

Four states have a "best-interests" or "best serve the needs" of the child and state (or society) standard. Del. Code ANs. tit. 10, § 937(15) (1975); Mich. Comp. Laws ANN. § 712 A.18 (Supp. 1975); VA. Code Anv. $\$ 16.1-178(4-1 / 2)$ (Supp. 1975) (preference to nearest kin); Wash. Rev. CoDE $\S 13.04 .095$ (Supp. 1975).

Many of the remaining states appear to have no standard for disposition at all, but instead leave the matter to the discretion of the judge. Several of these states have adopted the bestinterests-of-the-minor standard in their case law. See, e.g., Mitchell v. State, 142 So. $2 \mathrm{~d} 740$ (Fla. 2d Dist. Ct. of App. 1962); In re Augustus, 158 N.W.2d 625 (Iowa 1968); Booth v. Hennepin County Welfare Bd., 253 Minn. 395, 91 N.W.2d 921 (1958); In re Furrow, 187 Neb. 64, 187 N.W.2d 586 (1971). See generally Katz, Howe, \& McGrath, supra note 68.

82. See, e.g., Colo. Rev. Stat. Ann. § 19-1-102(b) (1974); Del. Code Ann. tit. $10 \S 902(a)$ (1975) ("to the end that the family will, if possible, remain unbroken"); IDAHO Code $\S 16-1624$ (Supp. 1974).

83. Preference for own home: Fla. Stat. AnN. \& 39.001(2) (1974); Hawail Rev. Stat. \& 571-1 (1968); INd. Code $\$ 31-5-7-1$ (1973); Kan. Stat. AnN. \$ 38-801 (1973); Mich. Comp. Laws AnN. $\S 712$ A.I (1968); Minn. Stat. Ann. $\S 260.011$ (1971); Miss. Code Ann. $\S 43-21-55$ (1972); Mo. ANN. Stat. \$211.011 (Vernon 1962); R.1. Gen. Laws ANs. § 14-1-2 (1970); S.D. Comp. Laws ANN. \$ 26-7-11 (Supp. 1974) ("due regard to the rightful parents and others directly interested"); Utah Code ANn. \$§55-10-63 (1974).

Remove only when welfare endangered: Colo. Rev. Stat. Ans. § 19-1-102(c) (1974) ("remove a child from the custody of his parents only when his welfare and safety or the protection of the public would otherwise be endangered"). See also Mass. Gen. Laws ANN. ch. 119, \& 1 (1975) ("substitute care of children only when the family itself or the resources available to the family are unable to provide the necessary care and protection to insure the rights of any child to sound 
However, few states have special additional statutory requirements that must be met before removal of a child over whom the court has jurisdiction, and none of these requires very specific determinations. ${ }^{84}$

\section{Inzoluntary Termination of Parental Rights-Adoption}

Adoption $^{85}$ in this country normally requires that the rights of the natural parent first be extinguished. In most cases, the natural parent or parents consent to the adoption. But if the natural parents withhold consent, state laws provide for adoption without such consent under specified circumstances. ${ }^{\mathbf{8 6}}$ Some states have separate proceedings for the involuntary termination of parental rights, and some authorize such termination as a remedy in neglect cases. ${ }^{87}$ Apart from contested termination proceedings, ${ }^{88}$ a custody dispute may arise if a natural parent challenges the adoption ${ }^{89}$ or attempts to withdraw his consent. ${ }^{90}$

Termination cases often involve the child-protection function: the state may initiate termination proceedings to free for adoption a child already a

health and normal physical, mental, spiritual and moral development"); R.I. Gex. Laws ANN. § 14-1-2 (1970).

84. See, e.g., ILl. ANN. STAT. ch. 37, § 705-7(1)(f) (1972) ("if the court finds that the parents ... are unfit or are unable, for some reason other than financial circumstances alone, to care for, protect, train or discipline the minor or are unwilling to do so, and that it is in the best interests of the minor to take him from the custody of his parents. . . the court may [do so]"); LA. REv. Stat. Ans. \& 13:1580(3) (Supp. 1975) ("nothing herein shall be construed as authorizing the removal of the child from the custody of his parents unless his welfare or the safety and protection of the public cannot, in the opinion of the court, be adequately safeguarded without such removal"); UTAH Code ANN. \$55-10-100(18) (1974) ("before depriving any parent of . . custody ... the court shall give due consideration to the preferred right of parents to the custody of their children, as expressed in [the purpose clause which expresses a preference for the child's ow'n home] and shall not [remove them] unless the court finds from all the circumstances... that the welfare of the child or the public interest requires that the child be taken from his home").

85. Adoption is the legal process by which a child acquires parents other than his natural parents, and parents acquire a child other than a natural child. The resulting legal relationship is identical to that of a natural parent and child. See, e.g., Wis. Stat. Ann. \$ 48.92 (Supp. 1975); lowa CODE $\$ 600.6(1970)$.

86. Although it appears that every state now allows adoption without consent of the natural parent, the procedures and standards used vary considerably. Many states allow adoption without consent provided a particular showing is made in the adoption proceeding itself. See, e.g., ME. Rev. Stat. AnN. tit. 19, § 1562 (1964).

A number of states have separate statutory proceedings for termination of the rights of the natural parents, quite apart from adoption. See, e.g., Conn. Gen. Stat. Ann. \& 45-51j (Supp. 1975). For a collection of statutory provisions concerning adoption without consent, see Simpson, The Unfit Parent: Conditions Under Which a Child May be Adopted Without the Consent of His Parent, 39 U. Der. L.J. 346, 360 n.89 (1962); Note, Adoption Law Reform, 19 ME. L. REv. 290, $318-19$ (1967).

87. Some states allow termination as a remedy in a neglect proceeding. See, e.g., lowa Codf AnN. $\$ 232.41$ (1969); Wis. Stat. Ann. \$ 48.40 (Supp. 1975).

88. See, e.g., In re Wardle, 207 N.W.2d 554 (Iowa 1973).

89. See, e.g., Dyer v. Howell, 212 Va. 453, 184 S.E.2d 789 (1971); Pratt v. Bishop, 257 N.C. 486,126 S.E.2d 597 (1962).

90. See, e.g., In re Capparelli, 180 Ore. 41, 175 P.2d 153 (1946); In re Harville, 233 La. 1. 96 So. 2d 20 (1957). See also Foster, Adoption and Child Custody: Best Interests of the Child?, 22 Buffalo L. REv. 1, 7-16 (1973). 
dependent of the juvenile court on the basis of allegations that the child has been neglected or abandoned by his natural parents. ${ }^{91}$ But termination proceedings may also arise out of situations where a stepparent wishes to adopt the child of his spouse and therefore seeks to terminate the parental rights of the noncustodial natural parent; ${ }^{92}$ and where contested, these cases involve the private-dispute-settlement as well.

The legal consequences of termination are substantial. Termination extinguishes the natural parent's duty to support the child ${ }^{93}$ and may affect the intestate inheritance relationship between the child and his natural parents. ${ }^{94}$ More significantly for present purposes, however, the natural parent's custodial rights are completely abolished.

Adoption and termination statutes are of comparatively recent origin. ${ }^{95}$ While these statutes vary considerably, ${ }^{96}$ "abandonment" of the child by his natural parent is the most common basis for allowing adoption without the parent's consent. ${ }^{97}$ Traditionally, such provisions have been rather inflexibly interpreted to require actual parental intent to abandon-behavior suggesting lack of interest has not been enough. ${ }^{\mathbf{9 8}}$ There are indications, however, that the legal standard for abandonment is becoming more discretionary and more child-centered: some movement can be detected, both legislatively and judicially, to permit children to be freed for adoption "when their parents manifest disinterest or inattention, regardless of subjective intent to abandon the child."99 For example, in a very recent case, the Alaska Supreme Court stated: ${ }^{100}$

91. See, e.g., In re Johnson, 9 Wis. 2d 65, 100 N.W.2d 383 (1960).

92. See, e.g., Malpass v. Morgan, 213 Va. 393, 192 S.E.2d 794 (1972); In re Clark, 183 N.W.2d 179 (lowa 1971).

93. See, e.g., Bentz v. Horr, 276 N.Y. 83, 11 N.E.2d 548 (1937); Ohio Rev. Code AnN. $\S 3107.13$ (Page 1972); Fla. Stat. Ann. § 63.172 (Supp. 1975).

94. States differ on this point. A few expressly dissolve the child's right to inherit intestate from the natural parents, see, e.g., Mich. Comp. Laws Ans. $\$ 710.60$ (Supp. 1975); OHIO Rev. Code Anv. \$ 3107.13 (Page 1972); others expressly retain such right, see, e.g., Me. Rev. Stat. ANn, tit. 19, 535 (1965). See also Roberts v. Roberts, 160 Minn. 140, 199 N.W. 581 (1924); Note, Inheritance-Adoption-Adopted Child Cannot Take Intestate From Natural Relatives, 12 WAYNE L. REv. 893 (1966).

95. While there was adoption under Roman law, it never became a part of the English common law. See Brosnan, The Law of Adoption, 22 Colum. L. Rev. 332, 335 (1922). Although legal fictions were used to reach the same result in extreme cases, see Huard, The Law of Adoption: Ancient and Modern, 9 VAND. L. Rev. 743, 747 (1956); not until 1926 was an adoption statute passed in England itself. Adoption of Children Act, 16 \& 17 Geo. 5 , c. 29 (1926). In the United States, except in states influenced by Roman and Civil law, see Huard, supra at 748; adoption statutes were first enacted in the mid to late nineteenth century. See Brosnan, supra at 335-36 for a brief review of early statutes.

96. For a compilation of state statutes, see Note, Adoption Law Reform, supra note 86, at 318-19.

97. See id.

98. See, e.g., In re Barazzi, 265 Cal. App. 2d 282, 71 Cal. Rptr. 249, 253 (1968). See also Bodenheimer, New Trends and Requirements in Adoption Law and Proposals for Legislative Change, 49 S. CAL. L. Rev. 10, 19-23 (1975).

99. See Bodenheimer, supra note 98 , at 23.

100. In re B.J., 530 A.2d 747, 749 (Alas. 1975) (footnotes omitted). 
We [have] defined abandonment as consisting of conduct on the part of the parent which implies a conscious disregard of the obligations owed by a parent to the child, leading to the destruction of the parent-child relationship, and held that it was not error for the trial court to consider the child's best interest in determining the issue of abandonment.

This, according to Professor Bodenheimer, "portends a shift toward greater strength of the interest of children vis-a-vis the rights of their absent parents." 101

Many states allow termination of parental rights for neglect ${ }^{102}$ or mistreatment. ${ }^{103}$ Usually, the "neglect" standard here is somewhat more stringent than for juvenile court jurisdiction. ${ }^{104}$ But several states allow a juvenile court that has assumed jurisdiction over a child to terminate parental rights if it is in the child's best interests. ${ }^{105}$ And some adoption statutes go so far as to allow adoption without natural parental consent if it is in the child's best interests. ${ }^{106}$ Even where the words of the standard are the same, however, one suspects that the social welfare officials and courts act more hesitantly when termination is the issue. ${ }^{107}$ Nevertheless, there appears to be some slight trend to give less weight to the claims of the natural parent.

\section{B. The Calls for Uniform Standards}

Reflecting impatience with the diminished differences among the standards applied in custody cases, the calls for a single standard for all disputes can now be heard in a variety of quarters: judicial, legislative, and scholarly. The Supreme Court of California recently held that the statutory provision governing divorce custody fights also applied to all custody decisions: ${ }^{108}$

Although the present appeal concerns a custody order under the Juvenile

Court Law, this procedural setting is fortuitous; the issue of custody could as

101. Bodenheimer, supra note 98, at 29.

102. See, e.g., Ariz. Rev. Stat. Anv. § 8-533(2) (1974); Hawali Rev. Stat. \$ 571.61 (b)(3) (1974) (if already in foster care); Idaho Code $\$ 16-1638$ (Supp. 1975); Mich. Comp. Law's ANN. \$ 712A.19a(e) (Supp. 1975) (if already in foster care); N.M. STAT. ANN. §§ 22-2-23, 23(3) (Supp. 1973); N.D. CENT. Code $§ 27-20-44$ (1974).

103. See, e.g., Okla. Stat. ANN. tit. 10, $\$ 1130(\mathrm{c})(2)$ (Supp. 1974); PA. Stat. AnN. tit. $1, \S$ $311(2)$ (Supp. 1974).

104. See, e.g., Fla. Stat. AxN, § 39.11(2)(d) (1974); Mins. Stat. ANN. § 260.22l(b)(3) (1971); In re K.S., 515 P.2d 130 (Col. App. 1973).

105. See Colo. Rev. Stat. Ann. \& 19-3-110(2)(a) (1974); Mont. Rev. Codes Ann. $\$$ $61-205(1)(c), 61-211$ (1970) (parent's consent not required if parent deprived of custody due to neglect or abuse; petition for adoption may be granted if in best interests of child); S.D. CoMP. Laws Ann. \& 26-8-36 (Supp. 1974); Vt. Stat. AnN. tit. 33, § 656(a)(3) (Supp. 1975); Wash. Rev. Code ANn. $\$ 13.04 .095,26.32 .040$ (2) (Supp. 1974); W. VA. Code ANx. \$ 49-6-5(3) (Supp. 1975).

106. See D.C. Code Anv. § 16-304(e) (1973); MD. Ans. Code art. 16, § 74 (1973); Mass. GeN. LAwS ANN. ch. 210, $\$ 3($ a)(ii) (Supp. 1975) (only if petition brought by person, licensed child-care agency, or state agency having custody of child); ch. $620, \S 4,1974$ Virginia Acts 1175 (see VA. CODE ANN. \$ 63.1-225 (Supp. 1975)).

107. See text at notes $210-19$ infra.

108. In re B.G., 11 Cal. 3d 679, 695-96, 523 P.2d 244, 255-56, 114 Cal. Rptr. 444, 455-56 (1974) (emphasis added). 
readily have been raised by an application for letters of guardianship, a writ of habeas corpus, or, had the father lived, an action for dissolution of marriage. In fact, California has at least eight separate proceedings in which custody questions can be litigated. . . There can be no question of the desirability of a uniform rule: the Legislature's specification that section 4600 applies to "any proceeding where there is at issue the custody of a minor child" demonstrates that section 4600 was enacted to fulfill that objective.

To the same end, the recently enacted Texas Family Code provides a uniform set of standards to govern all suits "affecting the parent-child relationship,"109 which include what would otherwise be divorce custody fights, child-neglect cases, and termination proceedings. ${ }^{110}$ And echoing this call from academic quarters is Beyond the Best Interests of the Child. ${ }^{11}$ Suggesting that legal standards now give too little weight to the psychological well-being of the child, Goldstein, Freud, and Solnit propose "generally applicable guidelines" to govern all "child placement" disputes. ${ }^{112}$

In each of these three examples, the applicable standards call for highly individualized determinations that focus on the child, not the parents. The California statute provides a series of statutory preferences. ${ }^{113}$ Custody may be awarded to a nonparent upon a finding "that an award to a parent would be detrimental to the child and the award to a nonparent is required to serve the best interests of the child."114 While refusing to adopt a naked bestinterests standard where a nonparent claims custody, the California Supreme Court in In re B.G. indicated that a natural parent who was not "unfit" could be deprived of custody "upon a clear showing that such award is essential to avert harm to the child." "15 The Texas statute allows substantial discretion, is

109. TEX. FAM. CODE $\$ 11.02(\mathrm{a})(1975)$.

110. A suit affecting the parent-child relationship is defined by the statute as one in which "the appointment of a managing conservator or a possessory conservator, access to or support of a child, or establishment or termination of the parent-child relationship is sought." Id. $\$ 11.01(5)$. Such a suit may be brought by any person with an interest in the child, including the child, a parent or relative, any agency of the state or of a political subdivision of the state, and any authorized agency. Id. $\$ 11.03$. A court must appoint a managing conservator (with power akin to a custodial spouse following divorce) whenever the court finds that the parents are or will be separated, id. $\$ 14.01(\mathrm{a})$; and may appoint one in any suit brought under the code's provisions. Id.

111. Goldstein, Freud, \& Solvit, supra note 1.

112. "Child placement" for our purposes is a term which encompasses all legislative, judicial and executive decisions generally or specifically concerned with establishing, administering, or rearranging parent-child relationships. The term covers a wide range of variously labeled legal procedures for deciding who should be assigned or expected to seize the opportunity and the task of being "parent" to a child. These procedures include birth certification, neglect, abandonment, battered child, foster care, adoption, delinquency, youth offender, as well as custody in annulment, separation and divorce. These labels, in many ways reminiscent of the stultifying common-law forms of action, have tended to obscure for scholar, draftsman, and practitioner, a problem common to all such procedures.

$I d$, at 5 .

113. See Cal. Civ. Code $\$ 4600$ (West Supp. 1975).

114. Id.

115. In re B.G., 11 Cal. 3d 679, 699, 523 P.2d 244, 258, 114 Cal. Rptr. 444, 458 (1974). 
riddled with references to the "best interests of the child,"116 and provides that custody should be given to the natural parent "unless the court finds that appointment of the parent would not be in the best interests of the child."117 And Goldstein, Freud, and Solnit would require a court to choose for a particular child the "least detrimental available alternative," which the authors define as: ${ }^{118}$

$[\mathrm{T}]$ hat child placement and procedure for child placement which maximizes, in accordance with the child's sense of time . . . the child's opportunity for being wanted ... and for maintaining on a continuous, unconditional, and permanent basis a relationship with at least one adult who is or will become the child's psychological parent.

Any "intervenor"- - hether the state, natural parents, or others-who wishes to alter a child's placement would have the burden of establishing that the child is unwanted, and if so, that his current placement is not the least detrimental alternative. The focus would be exclusively on the interests of the child, and no preference would be given to the natural parent as such. ${ }^{119}$

The distinction offered earlier between the child-protection and the private-dispute-settlement functions helps explain why critics might be impatient with the remaining differences among the standards for the four strands of custody law. Either function can be involved in a judicial proceeding involving the application of any of the four strands of custody law, and a single case may involve both functions. Divorce custody law and guardianship law, for example, nearly always involve the private-dispute-settlement function, but either can involve the child-protection function as well if a court is required to evaluate a contention that one of the claimants would endanger a child. ${ }^{120}$ Cases involving the application of juvenile court child-neglect laws or laws relating to termination of parental rights normally involve the child-protection function-usually an agency of the state is asking the court to deny custody to a child's parent or parents on the basis of allegations that abuse or neglect endangers the child. The private-dispute-settlement function may be involved as well, however, if there are competing private parties, each prepared to make a long-term commitment to the child. And both functions are involved where, for example, a noncustodial father initiates a juvenile court childneglect proceeding in order to remove a child from his former wife's custody and have the juvenile court place the child with him. ${ }^{121}$ Similarly, a proceeding to terminate parental rights may also involve the judicial resolution of a

116. See, e.g., TEX. FAM, Code $\$ \$ 14.01(b)(c), 14.08(c)(1975)$.

117. Id. $\$ 14.01(\mathrm{~b})$.

118. Goldstein, Freud, \& Solnit 99.

119. See id. at 100 .

120. See text at note 230 infra.

121. See, e.g., In re Anonymous, 37 Misc. 2d 411, 238 N.Y.S.2d 422 (Rennsselaer County Family Ct. 1962). 
private dispute where it is initiated by a stepparent who wishes to adopt a child over the objection of a noncustodial natural parent. ${ }^{122}$

Significantly, both In re B.G. ${ }^{123}$ and the Rothman case ${ }^{124}$ - used by Goldstein, Freud, and Solnit to illustrate their proposed standard-involved a custody fight between a natural parent who had no recent contact with the child and foster parents who had a substantial relationship with the child and who did not wish to give up custody. Thus, both cases were juvenile court proceedings that were private disputes between claimants prepared to make a longterm commitment to the child. In such circumstances, to use a standard different from that employed in private disputes in the divorce or the guardianship context seems anomalous, particularly if one believes that the child's needs should be the primary focus and that biological parenthood should not be dispositive. ${ }^{125}$ After all, if one's chief concern is with the child rather than with the impact on the parents or the legal consequences of the proceeding, then the "fortuity" of the strand of law invoked becomes an unacceptable basis for applying a different legal standard. But for reasons developed later in this article, the adoption of a single set of standards confuses the two different judicial functions and risks very adverse policy consequences. To show this, however, requires first an analysis of how the highly individualized determinations of what is either detrimental or in the best interests of a particular child contrast with the kinds of determinations usually required of courts in adjudication.

\section{An Analysis of Present-Day Custody Standards}

\section{A. How Custody Disputes Contrast With Traditional Adjudication}

At the core of adjudication is the notion that government exercises authority through a process in which the persons affected can participate. ${ }^{126}$ Each

122. See, e.g., Dyer v. Howell, 212 Va. 453, 184 S.E.2d 789 (1971) (adoptive parent versus father in termination proceeding).

123. I I Cal. 3d 679, 523 P.2d 244, 114 Cal. Rptr. 444 (1974).

124. Rothman v. Jewish Child Care Ass'n, 167 N.Y.L.J. 17 (1972).

125. See Goldstein, Freud, \& Solnit 71-95. Because removal of the child from the custody of the foster parents in the circumstances of these cases might endanger the child's psychological health, see id., these cases might be characterized as also involving child protection. In extreme cases like these, where one claimant is a stranger to the child and the other is not, I would prefer the "psychological parent" to a natural parent who is a stranger. See text at notes 231, 243-44 supra.

126. Eisenberg has defined adjudication as "an institutionalized dispute-settlement process in which a third party has formal power to render an authoritative (although not necessarily binding) judgment on the basis of reasoned considerations, after affording both disputants the opportunity of making reasoned arguments and proof." $M$. Eisenberg, supra note 21, at 99. He distinguishes and compares adjudication as a mode of dispute-resolution with negotiation and mediation. 
party has an "institutionally guaranteed ... opportunity to present proofs and arguments for a decision in his favor." 127 A neutral judge ${ }^{128}$ resolves the dispute by ascertaining past events and evaluating those past events against articulated and described legal standards that are generally applicable. As part of this process, the judge is obliged to reconcile the rules used to evaluate these past events with those announced and applied in earlier disputes of the same sort. ${ }^{129}$ The parties then usually may ask some higher court to review the decision to determine whether the appropriate rules were applied and, to a limited extent, whether the past events were accurately ascertained. Childcustody disputes resolved under the broad best-interests-of-the-child principle differ from this model of adjudication in several closely interrelated ways.

\section{1. "Person-Oriented" Not "Act-Oriented" Determinations}

The first and most striking difference relates to a distinction suggested by Lon Fuller: custody disputes under the best-interests principle require "person-oriented," not "act-oriented," determinations. ${ }^{130}$ Most legal rules require determination of some event and are thus "act-oriented."131 A "person-

127. Fuller, Collective Bargaining and the Arbitrator, 1963 Wis. L. REv, 3, 19.

128. Neutrality does not require that the adjudicator be a stranger to the disputants. Eisenberg sorts adjudication into two categories: (1) impersonal adjudication, where the adjudicator is neutral and a stranger to the disputants; and (2) intimate adjudication, where the adjudicator is neutral but an intimate of the disputants, in that he shares with them membership in a relatively small, cohesive group. An impersonal adjudicator necessarily has the power to impose a settlement, while an intimate may or may not. See M. Eisenberg, supra note 21 , at 99.

129. "It is this commitment to governance by rules-and not only restrained by or even guided by rules-that characterizes adjudication as a special way of exercising authority." P. Nonet, Administrative Justice: Advocacy and Change in a Government Agency 201 (1969). The nature of legal rules and the role in adjudication is. of course, the subject of continuing jurisprudential and philosophical concern. Whether legal rules control the process by which a legal conclusion is reached, serve as "tools for guiding inferences," or merely play a role in justifying a conclusion already reached is the subject of substantial literature. See J. FRANK, LAW AND the Modern Mind (1936); G. Gottleb, The Logic of Choice 71.74 (1968); R. Wasserstrom, The Judicial Decision: Toward a Theory of Legal Justification (1961); Hart, Positizism and the Separation of Law and Morals, 71 HARV. L. Rev. 593 (1958). Fortunately, an analysis of custody disputes does not require the resolution of this protracted debate. Moreover, the highly idealized version of adjudication presented here is not meant to describe completely the way judges resolve social tasks assigned for adjudication nor to suggest that courts should never be assigned tasks that do not fit neatly within the traditional model. Courts today have, in fact, assumed responsibility for deciding types of disputes that in decades past were considered unmanageable. Compared with fashioning integration decrees or reapportioning state legislatures, the judicial resolution of a custody dispute may seem quite conventional. Nevertheless, a model of traditional adjudication does help expose how the resolution of custody disputes under a broad best-interests principle differs from most adjudication.

130. See L. Fuller, Interaction Between Law and Its Social Context 8 (item 3 of unbound class material for Sociology of Law', Summer 1971, University of California, Berkeley) [hereinafter cited as Interaction Between Law and Its Social Context]. See also Fuller, Two Principles of Human Association, in Nomos XI, at 3, 17-19 (J. Pennock \& J. Chapman eds. 1969).

131. See M. Eisenberg, supra note 21 , at 42. 
oriented" rule, on the other hand, requires an evaluation of the "whole person viewed as a social being." 132 Several of the other important ways in which child-custody disputes differ from the paradigm of adjudication follow from this feature of person- rather than act-orientation.

Normally, adjudication involves application of act-oriented rules and thus avoids broad evaluation of a litigant as a social being. For example, in a dispute in which Adams sues Brown alleging that Brown trespassed on land that Adams owns, Brown may defend on the ground that Adams six years earlier had given him permission to cross over the land and that Brown had done so daily ever since. To decide this case, a judge will seek to determine what actually happened between Adams and Brown. If the evidence indicates that in some way Adams may have assented to Brown's entering the property, the judge will consider what act or acts are sufficient to make entry lawful. Is acquiescence enough? For how long must it take place? Does the law require some formal means of granting permission in order to grant a permanent right to cross the Adams property? In deciding this kind of litigation, it will not be remotely relevant which disputant has more money, is more humane, works harder, gives more to charity, follows better religious practices, or takes better care of his house. The resolution will only be person-oriented to the extent that the judge must evaluate each as a social being in order to determine whether one should be considered more credible than the other.

Resolution of a custody dispute by the best-interests-of-the-child principle stands in sharp contrast to the foregoing. In a divorce custody fight, a court must evaluate the attitudes, dispositions, capacities, and shortcomings of each parent to apply the best-interest standard. Indeed, the inquiry centers on what kind of person each parent is, and what the child is like. ${ }^{133}$ That there is, however, nothing inherent in custody disputes requiring resolution by a person-oriented rule is shown by the nineteenth-century examples of actoriented rules for custody disputes between a child's parents.

\section{Predictions Not Determinations of Past Acts}

Adjudication usually requires the determination of past acts and facts, not a prediction of future events. Applying the best-interests standard requires an individualized prediction: with whom will this child be better off in the years to come? Proof of what happened in the past is relevant only insofar as it enables the court to decide what is likely to happen in the future.

While most disputes resolved by adjudication do not require predictions, there are other areas of the law that involve legal standards that do. The

132. Interaction Between Law and Its Social Context 9.

133. See text at notes 32-35 supra; $c$. Interaction Between Law and Its Social Context. 
standards governing preventive detention, ${ }^{134}$ pretrial detention, ${ }^{135}$ and sentencing are conspicuous examples. ${ }^{136}$ The Clayton Act by its terms condemns practices where "the effect ... may be substantially to lessen competition, or to tend to create a monopoly." ${ }^{137}$ Where courts are required to make predictions, however, they often attempt to formulate rules of thumb or presumptions that make the outcome turn in a systematic way on the showing of certain ascertainable facts about the past. Under the Clayton Act, for example, rules for horizontal mergers, in effect, presume adverse competitive effects from a demonstration that the merging companies presently have a particular share of existing markets. ${ }^{138}$ More generally, when courts are required to make predictions, they often attempt to develop subsidiary rules that relate certain ascertainable facts about the present or past in a systematic way to the future. ${ }^{139}$ They thus do not purport to make individualized predictions, but rather apply rules.

\section{Interdependence of Outcome-Affecting Factors}

Because custody disputes involve relationships between people, a decision affecting any one of the parties will often necessarily have an effect on the others. The resolution of a custody dispute may permanently affect-or even end-the parties' legal relationship; but the social and psychological relationships will usually continue. The best-interests principle requires a prediction of what will happen in the future, ${ }^{140}$ which, of course, depends in part on the future behavior of the parties. Because these parties will often interact in the future, this probable interaction must be taken into account in deciding what the outcome is to be. ${ }^{141}$ For example, awarding custody to the mother may

134. See, e.g., Cal. Welf. \& INst'ns Code $\$ 5150$ (West Supp. 1975) (allowing commitment if a person is a danger to himself or others); MD. ANn. Code art. 59, \$12 (1972). See also Diamond, The Psychiatric Prediction of Dangerousness, 123 U. PA. L. REv. 439 (1974).

135. See 18 U.S.C. $\$ 3146$ (1970) (requiring pretrial release unless various conditions will "not reasonably assure the appearance of the person as required"); $c f$. D.C. CoDE ANs. $\S 23-$ 1322 (1973) (allowing pretrial detention upon certain findings, including one in which there is "no condition or combination of conditions which will reasonably assure the safety of the community").

136. See generally L. Orland, Justice, Punishment and Treatment (1973).

137. 15 U.S.C. $\$ 18(1970)$.

138. See United States v. Von's Grocery, 384 U.S. 270 (1966).

139. Compare Brown Shoe Co., Inc. v. United States, 370 U.S. 294 (1962) (many factors to be considered in evaluating probable competitive effect of horizontal merger), with United States $v$. Von's Grocery, 384 U.S. 270 (1966) (existing market shares of merging company and past trend toward concentration enough to condemn merger between two grocery chains). But cf. United States v. General Dynamics Corp., 415 U.S. 486 (1974). Insofar as rehabilitation or special deterrence are goals, criminal sentencing requires predictions; but courts here have conspicuously failed to develop such rules.

140. See Watson, supra note 5 , at 71 .

141. Interdependence or "multicollinearity" are terms sometimes used in statistical regression 
affect the father's behavior, which, in turn, can affect the mother's behavior and the child. The possibility of such feedback must be considered in applying the best-interests standard. ${ }^{142}$ Most disputes resolved by adjudication do not require predictions involving appraisals of future relationships where the "loser's" future behavior can be an important ingredient.

\section{Findings, Precedent, and Appellate Review}

A determination that is person-oriented and requires predictions necessarily involves an evaluation of the parties who have appeared in court. This has important consequences for the roles of both precedent and appellate review in custody cases. The result of an earlier case involving different people has limited relevance to a subsequent case requiring individualized evaluations of a particular child and the litigants. Prior reported cases now provide little basis for controlling or predicting the outcome of a particular case. ${ }^{143}$ Moreover, the trial court in custody disputes is often not required to make specific

analysis to describe the relationship between explanatory variables that are themselves not independent. As a consequence, "it becomes very difficult, if not impossible, to disentangle [the] separate influences [of the explanatory variables] and obtain a reasonably precise estimate of their relative effects. See J. Johnston, Econometric Methods 201 (1963).

142. My notion of "interdependence" differs from, but is related to, Fuller's idea of "polycentricity." Fuller's definition appears to turn primarily on the problem of division-e.g., dividing a decedent's art collection among various heirs. He points out that most disputes decided by adjudication call for either a yes/no or a more/less determination. Fuller, supra note 127, at 31-34. A polycentric is one where a web of interrelationships is set off by any change in division:

There is no single solution, or simple set of solutions, toward which the parties meeting in open court could address themselves. . . . One may illustrate the essential idea by a spiderweb. Pull a strand here, and a complex pattern of adjustments runs through the whole web. Pull another strand from a different angle, and another complex pattern results.

Id. at 33. A child custody case can be resolved by a yes/no determination: custody can be given to one disputant. Alternatively, by varying the amount of visitation, the resolution can be characterized as a morelless determination. Thus, a child-custody dispute is not, in this sense, polycentric. But like a polycentric dispute, a child-custody case does pose procedural difficulties by having too many outcomes for the parties to address efficiently within an adjudicatory framework. When there are several different variables that can affect the prediction the court is required to make and they are interdependent, changing one variable can affect several of the other variables, and all, in turn, can affect the result. Like Fuller's polycentric dispute, an interdependent dispute is one in which there is no single or simple set of solutions towards which the parties meeting in open court can address themselves.

143. Appellate courts have frequently stated that precedent is of little relevance in custody disputes. See, e.g., Nye v. Nye, 343 Ill. App. 477, 483, 99 N.E.2d 574, 576 (1951):

We have read the many cases from this and foreign jurisdictions, cited by the parties, on the question of priority of right to custody. There is no definitive rule stated in the cases we have read which would control our decision. Each case stands on its own facts. It is clear, however, that the courts are influenced by one or more of many factors, including the age, health and sex of the child; the characters and material circumstances of the parties; preference indicated by the child; cause of the divorce; to whom the divorce was given; and the future welfare of the child. . . The welfare of the child is the principle of decision. 
findings of fact, much less write an. opinion about the case or reconcile what has been done in this case with what has happened before. ${ }^{144}$

All of this makes the scope of appellate review extremely limited. Because the trial court's decision involves an assessment of the personality, character, and relationship of people the judge has seen in court, appellate courts are extremely loath to upset the trial court's determination on the basis of a transcript. In the words of an English judge, "So much may turn, consciously or unconsciously, on estimates of character which cannot be made by those who have not seen or heard the parties." 145 As Professor Fuller has written, "It would be hard [for an appellate court to pass an intelligent judgment on the trial court's decision] unless it were prepared to summon the husband, wife and child before it and try the case over again." 146 For this reason, the oftenstated rule is that an appellate court cannot interfere with the determination of a trial judge in a custody dispute unless the lower court has exercised its discretion on some wrong general principle ${ }^{147}$ or taken an inappropriate factor into account. ${ }^{48}$ But since only the broadest principle is typically announced in these decisions, it is difficult to know when a trial judge has acted upon some inappropriate principle or factor. Constrained little by precedent or appellate review, the trial court's discretion is very wide indeed.

\section{Participation by All Affected Parties}

Normally, parties most obviously affected by a dispute have a right to participate in the adjudicatory process. The issue in a child-custody dispute is what will become of the child, but ordinarily the child is not a true participant in the process. While the best-interests principle requires that the primary focus be on the interests of the child, the child ordinarily does not define those interests himself, ${ }^{149}$ nor does he have representation in the ordinary sense. ${ }^{150}$ Even in states that allow for independent representation for the

144. See, e.g., Chaffin v. Frye, 45 Cal. App. 3d 39, 119 Cal. Rptr. 22, 24 (1975) (dispositional standard requires findings but not written findings).

145. In re B.(T.A.) (An Infant), [1971] 1 Ch. 270 (1970).

146. Interaction Between Law and Its Social Context 10.

147. See Pace, Custody and Appellate Courts, 3 FamiLy Law 27 (1973).

148. Compare In re A.J., 274 Cal. App. 2d 199, 78 Cal. Rptr. 880 (1969), with Chaffin v. Frye. $45 \mathrm{Cal}$. A pp. 3d 39, 119 Cal. Rptr. 22 at 25-26 ("[i]n exercising a choice between homosexual and heterosexual households for purposes of child custody a trial court could conclude that permanent residence in a homosexual household would be detrimental to the children and contrary to their best interests").

149. The preference of the child above the age of discretion may be given weight in the judge's decision, but it is normally not controlling. Instead, it is only a factor for the court to consider. See, e.g., McGregor v. McGregor, 257 Ala. 232, 58 So. 2d 457 (1952). For children twelve years of age or over, the preference is sometimes made dispositive, unless the chosen parent is unfit. See Ohro Rev. Code Axs. $\$ 3109.04$ (Page 1975). See also text at notes 168 infra \& 142 supra.

150. The Uniform Marriage and Divorce Act provides that "the court may appoint an attor- 
child in the dispute, the role of the child's advocate is different from that in normal adjudication. A lawyer usually looks to his client for instructions about the goals to be pursued. Except in the case of older children, a child's representative in a custody dispute must himself normally define the child's interests. ${ }^{151}$

\section{B. The Indeterminacy of Present-Day Standards}

Lon Fuller has suggested that when a judge decides about custody under the best-interests principle, he is: ${ }^{152}$

[N]ot applying law or legal rules at all, but is exercising administrative discretion which by its nature cannot be rule-bound. The statutory admonitions to decide the question of custody so as to advance the welfare of the child is as remote from being a rule of law as an instruction to the manager of a stateowned factory that he should follow the principle of maximizing output at the least cost to the state.

Insofar as a court assumes responsibility for seeing how a child is to be raised, it is assuming a managerial role. ${ }^{153}$

When a judge must resolve a custody dispute, he is committed to making a choice among alternatives. The very words of the best-interests-of-the-child principle suggest that the judge should decide by choosing the alternative that "maximizes" what is best for a particular child. ${ }^{154}$ Conceived this way, the judge's decision can be framed in a manner consistent with an intellectual tradition that views the decision process as a problem of rational choice. In analyzing the custody decision from this perspective, my purpose is not to describe how judges in fact decide custody disputes nor to propose a method

ney to represent the interests of a minor or dependent child with respect to his custody, support, and visitation." Uniform Marriage and Divorce Act $\$ 301$ (emphasis added). See also Wis. STat. ANN. $\$ 247.045$ (Supp. 1975) (providing for appointment "when the court has reason for special concern"), and Wendland v. Wendland, 29 Wis. 2d 145, 155-57, 138 N.W.2d 185, 191 (1965); Hansen, Guardians Ad Litem in Divorce and Custody Cases: Protection of the Child's Interests, $4 \mathrm{~J}$ Family Law 181 (1964): The Role and Rights of Children in Divorce Actions, 6 J. Family Law 1 (1966).

151. See A.B.A. Code of Professional Responsibility Canon No. 7, Ethical ConsidERATIONS 7-11, 7-12 (1969). For discussions of the problem in the Juvenile Court context, see Kay \& Segal, The Role of the Attorney in Juvenile Court Proceedings: A Non-Polar Approach, 61 GEO. L.J. 1401 (1973); Comment, The Attorney-Parent Relationship in the Juvenile Court, 12 Sr. LouIs L.J. 603 (1968).

152. Interaction Between Law and Its Social Context 11.

153. Regulatory agencies, such as the CAB, FCC, and ICC, often perform managerial functions within the context of adjudicatory proceedings. But quaere: with what success? See generally G. Robinson \& E. Gellhorn, The Administrative Process 139-341 (1974).

154. To choose what is least detrimental can be put in exactly the same conceptual framework. It too requires both the specification of alternative outcomes and the assessment of probabilities. The least detrimental alternative is then chosen. Detriment can be regarded as a utility measure that takes into account only harm. Alternatively, detriment may be defined simply as the absence of benefit, in which case it is best interests under a different name. In either event, the specification of a utility function presents the same conceptual difficulties. 
of how they should. Instead, it is to expose the inherent indeterminacy of the best-interests standard.

\section{Rational Choice}

Decision theorists have laid out the logic of rational choice with clarity and mathematical rigor for prototype decision problems. ${ }^{155}$ The decision-maker specifies alternative outcomes associated with different courses of action and then chooses that alternative that "maximizes" his values, subject to whatever constraints the decision-maker faces. This involves two critical assumptions: first, that the decision-maker can specify alternative outcomes for each course of action; the second, that the decision-maker can assign to each outcome a "utility" measure that integrates his values and allows comparisons among alternative outcomes. ${ }^{156}$ Choice does not require certainty about the single outcome that will in fact flow from a particular action. Treating uncertainty as a statistical problem, models have been developed that allow decisions to be made on the basis of "expected" utility. This requires that the decision-maker be able to specify the probability of each possible outcome for a particular course of action. The utility of each possible outcome is then discounted by its probability. ${ }^{157}$

Decision-making under this model also implies certain things about the process. The decision-maker will be receptive and sensitive to informational requirements and will modify his outcome calculations as new information becomes available: ${ }^{158}$

155. See generally R. Luce \& H. Raiffa, Games and Decisions (1957). Various disciplines have elaborated on these models. Economists, for example, have used variations on the model to describe and prescribe "rational" consumer behavior and the activities of business firms in competitive markets. See P. Samuelson, Economics (8th ed. 1970); W. Baumol, Economic Theory and Operations Analysis (1965). Rational choice with regard to the procurement of weapons systems and public investment in water resources similarly have been described by policy analysts using the theoretical perspectives of decision theory. See C. Hitch \& R. MCKean, The Economics of Defense in the Nuclear Age (1960); O. Eckstein, Water-Resource Development (1961). And this theory also has been used as one paradigm to describe the Cuban Missile Crisis. See G. Allison, Essence of Decision: Explaining the Cuban Missile Crisis (1971). For an extremely interesting analysis of the paradigmatic nature of rational decision theory and its comparison with another theoretical paradigm, see J. Steinbruner, The Cybernetic Theory of Decision: New Dimensions of Political Analysis (1974).

156. Another requirement is that the decision-maker's preferences be transitive-that is, for a given order of three alternatives, if $A$ is preferred to $B$, and if $B$ is preferred to $C$, then $A$ must be preferred to $C$. See J. Steinbruner, supra note 155 , at 28 . For a mathematical treatment of this model, see H. Simon, A Behavioral Model of Rational Choice, in Models of Man: Social and Rational: Mathematical Essays on Rational Human Behavior in a Social Setting 241-60 (1957).

157. See generally H. Raiffa, Decision Analysis, Introductory Lectures on Choices Under UNCERTAINTY (1968). Cf. Learned Hand's formulation of the negligence rule in United States v. Carroll Towing Co., 159 F.2d 169 (2d Cir. 1947).

158. J. Steinbruner, supra note 155, at 35-36. 
The quintessential analytic decision-maker is one who strains towards as complete an understanding as possible of the causal forces which determine outcomes. He seeks to predict the flow of events and, where he has leverage, to manipulate them to his advantage. The processing of information on making decisions is all done for the purposes of constructing and improving the blueprint from which the optimal choice emerges.

Unlike adjudication, rational choice does not require participation of the affected parties, the use of precedents or rules, or review; today's decision need not be reconciled with similar decisions made earlier.

\section{A Custody Determination Under the Best-Interests-of-the-Child Principle}

Assume that a judge must decide whether a child should live with his mother or his father when the parents are in the process of obtaining a divorce. ${ }^{159}$ From the perspective of rational choice, the judge would wish to compare the expected utility for the child of living with his mother with that of living with his father. The judge would need considerable information and predictive ability to do this. The judge would also need some source for the values to measure utility for the child. All three are problematic.

\section{a. The Need for Information: Specifying Possible Outcomes}

In the example chosen, the judge would require information about how each parent had behaved in the past, how this behavior had affected the child, and the child's present condition. Then the judge would need to predict the future behavior and circumstances of each parent if the child were to remain with that parent and to gauge the effects of this behavior and these circumstances on the child. He would also have to consider the behavior of each parent if the child were to live with the other parent and how this might affect the child. If a custody award to one parent would require removing the child from his present circumstances, school, friends, and familiar surrounding, the judge would necessarily wish to predict the effects these changes would have on the child. These predictions would necessarily involve estimates of not only the child's mutual relationships with the custodial parent, but also his future contacts with the other parent and siblings, the probable number of visits by the noncustodial spouse, the probable financial circumstances of each of the spouses, and a myriad of other factors.

One can question how often, if ever, any judge will have the necessary information. In many instances, a judge lacks adequate information about even the most rudimentary aspects of a child's life with his parents and has still less information available about what either parent plans in the future.

159. The same analysis would apply in a state-initiated neglect proceeding. See generally Mnookin, supra note 4. 
This is particularly true in many juvenile court proceedings where, at the time of the dispositional hearing, the judge typically has no information about where the child will be placed if removal is ordered. The judge usually knows nothing about either the characteristics of the foster family or how long that family will want or be able to keep the child. Indeed, in these custody cases, the court is normally comparing an existing family with an unknown alternative. ${ }^{160}$

\section{b. Predictions Assessing the Probability of Alternative Outcomes}

Obviously, more than one outcome is possible for each course of judicial action, so the judge must assess the probability of various outcomes and evaluate the seriousness of possible benefits and harms associated with each. But even where a judge has substantial information about the child's past home life and the present alternatives, present-day knowledge about human behavior provides no basis for the kind of individualized predictions required by the best-interests standard. There are numerous competing theories of human behavior, based on radically different conceptions of the nature of man, and no consensus exists that any one is correct. ${ }^{161}$ No theory at all is considered widely capable of generating reliable predictions about the psychological and behavioral consequences of alternative dispositions for a particular child.

While psychiatrists and psychoanalysts have at times been enthusiastic in claiming for themselves the largest possible role in custody proceedings, many have conceded that their theories provide no reliable guide for predictions

160. See Mnookin, supra note 4, at 616.

161. While a book could be written to document this proposition, a comparison of five sample theories with competing implications should suffice for these purposes:

1. Physiologically-oriented theories suggest that a child's personality is primarily determined by his physical structure or body type. See, e.g., W. Sheldox, The Varieties of Human Physique: An Introduction to Constitutional Psychology (1940).

2. Behaviorist theories view the child as broadly malleable and suggest that his personality development is shaped by environment through a system of reward and punishment. See, e.g., J. Watson, Behaviorism (1920); B. SkinNer. Walden II (1948) (affording an extreme perspective on the implications possible in child rearing).

3. Psychoanalytic theories suggest that the interaction between parent and child sets into motion various developmental and unconscious forces that are the wellsprings of behavior. Freud stresses the importance of the first few years of life. when the child goes through distinct developmental stages. The parents' response to these stages will be the major determinant of the child's later personality. See generally S. Freud, Beyond the Pleasure Principle, in 18 Collected Works 7, 20-21 (J. Strachey ed. \& transl. 1955).

4. Child-development and learning theories present the child as an active participant in the world around him, basically self-generating and activated by innate tendencies towards involving himself with his environment. See, e.g., J. Piaget, The Origins of Intelligence in Children (1952).

5. Interpersonal theories suggest that a child's developing personality is largely determined by the roles and expectations assigned to him by his family. See, e.g., H. Sullivar, The Interpersonal Theory of Psychiatry (1953). 
about what is likely to happen to a particular child. ${ }^{162}$ Anna Freud, who has devoted her life to the study of the child and who plainly believes that theory can be a useful guide to treatment, has warned: "In spite of . . advances there remain factors which make clinical foresight, i.e., prediction, difficult and hazardous," not the least of which is that "environmental happenings in a child's life will always remain unpredictable since they are not governed by any known laws. ..."163

The difficulty of making accurate predictions is shown clearly by a study undertaken by Joan Macfarlane and her associates in Berkeley, California. ${ }^{164}$ Using various tests and interviews, the Berkeley group, during a thirty-year period, studied a group of 166 infants born in 1929. Their objective was to observe the growth-emotional, mental, and physical-of normal people. As Arlene Skolnick observed, "Over the years this study has generated several significant research findings, but the most surprising of all was the difficulty of predicting what thirty-year-old adults would be like even after the most sophisticated data had been gathered on them as children. . . ."165

Various studies have attempted to trace personality development to specific antecedent variables to show that these variables have the same effects on different children. This connection is now widely questioned by experimental psychologists such as H. R. Schaffer, who thinks that infants experience external events in individual ways. ${ }^{166}$ The implication of this for predic-

162. See, e.g., Ellsworth \& Levy, supra note 6.

163. A. FReud, Child Observation and Prediction of Development-A Memorial Lecture in Honor of Ernst Kris, in 13 The Psychoanalytic Study of The Child 92, 97-98 (1958). See also Goldstein, Freud, \& Solvit 51-52; Goldstein, Psychoanalysis and Jurisprudence, 71 YALE L.J. 1053 (1968). The limitations of psychological theory in generating verifiable predictions is suggested by the numerous studies that have attempted to trace effects of various child rearing techniques and parental attitudes on adult personality traits. See, e.g., S. Escalona, The Roots of Individuality: Normat. Patterns of Development in Infancy 13 (1968). For an analysis of the difficulties of predicting dangerousness in the civil commitment context, see Diamond, supra note 134.

164. See Macfarlane, Perspectives on Personality Consistency and Change from the Guidance Study, 7 Vita Humana 115 (1964).

165. A. Skolnick, The Intimate Environment, Exploring Marriage and the Family 378 (1973). Skolnick explained the results as follows:

Foremost, the researchers had tended to overestimate the damaging effects of early troubles of various kinds. Most personality theory had been derived from observations of troubled people in therapy. The pathology of adult neurotics and psychotics was traced back to disturbances early in childhood-poor parent-child relations, chronic school difficulties, and so forth. Consequently, theories of personality based on clinical observation tended to define adult psychological problems as socialization failures. But the psychiatrist sees only disturbed people; he does not encounter "normal" individuals who may experience childhood difficulties, but who do not grow into troubled adults. The Berkeley method, however, called for studying such people. Data on the experience of these subjects demonstrated the error of assuming that similar childhood conditions affect every child the same way. Indeed, many instances of what looked like severe pathology to the researchers were put to constructive use by the subjects... Id. at 379 .

166. See H. Schaffer, The Growth of Sociability 16 (1971). 
tion is described very well by Skolnick: "[I]f the child selectively interprets situations and events, we cannot confidently predict behavior from knowledge of the situation alone." 167

\section{c. Values to Inform Choice: Assigning Utilities to Various Outcomes}

Even if the various outcomes could be specified and their probability estimated, a fundamental problem would remain unsolved. What set of values should a judge use to determine what is in a child's best interests? If a decision-maker must assign some measure of utility to each possible outcome, how is utility to be determined?

For many decisions in an individualistic society, one asks the person affected what he wants. Applying this notion to custody cases, the child could be asked to specify those values or even to choose. In some cases, especially those involving divorce, the child's preference is sought and given weight. ${ }^{168}$ But to make the child responsible for the choice may jeopardize his future relationship with the other parent. And we often lack confidence that the child has the capacity and the maturity appropriately to determine his own utility.

Moreover, whether or not the judge looks to the child for some guidance, there remains the question whether best interests should be viewed from a long-term or a short-term perspective. The conditions that make a person happy at age seven to ten may have adverse consequences at age thirty. Should the judge ask himself what decision will make the child happiest in the next year? Or at thirty? Or at seventy? Should the judge decide by thinking about what decision the child as an adult looking back would have wanted made? In this case, the preference problem is formidable, for how is the judge to compare "happiness" at one age with "happiness" at another age? 169

Deciding what is best for a child poses a question no less ultimate than the purposes and values of life itself. Should the judge be primarily concerned with the child's happiness? Or with the child's spiritual and religious training? Should the judge be concerned with the economic "productivity" of the child when he grows up? Are the primary values of life in warm, interpersonal relationships, or in discipline and self-sacrifice? Is stability and security for a child more desirable than intellectual stimulation? ${ }^{170}$ These questions could be elaborated endlessly. And yet, where is the judge to look for the set of values that should inform the choice of what is best for the child? Normally, the custody statutes do not themselves give content or relative weights to the pertinent values. And if the judge looks to society at large, he finds neither a

167. А. SкоLNick, supra note 165 , at 372 .

168. See note 149 supra \& text at note 242 infra.

169. Because of the difficulties of making long-term predictions, it has been suggested that only short-run effects be considered. See Goldstein, Freud, \& Solnit 51-52.

170. See Painter v. Bannister, 258 lowa 1390, 140 N.W.2d 152, 154 (1966). 
clear consensus as to the best child rearing strategies nor an appropriate hierarchy of ultimate values.

It thus seems clear that a judge in a child-custody case is in a more difficult position than Professor Fuller's factory manager told to maximize his output or profits. While the factory manager's problems of prediction are formidable, he at least has a measure to compare the relative value of possible outcomes. Physical output or money profits, given existing resources, can be maximized. But in a child-custody dispute, what comparable measure does a judge have in a society that lacks a clearly defined and integrated set of values about what is good for particular individuals?

\section{Why Some Custody Cases Are Easy to Decide}

An inquiry about what is best for a child often yields indeterminate results because of the problems of having adequate information, making the necessary predictions, and finding an integrated set of values by which to choose. But some custody cases may still be comparatively easy to decide. While there is no consensus about what is best for a child, there is much consensus about what is very bad (e.g., physical abuse); some short-term predictions about human behavior can be reliably made (e.g., chronic alcoholism or psychosis is difficult quickly to modify). Asking which alternative is in the best interests of a child may have a rather clear-cut answer in situations where one claimant exposes the child to substantial risks of immediate harm and the other claimant already has a substantial personal relationship with the child and poses no such risk. In a private dispute between two parents, for example, if a judge could predict that one parent's conduct would seriously endanger the child's health, it would not be difficult to conclude that the child's expected utility would be higher if he went with the other parent, whose conduct did not, even without the necessity of defining utility carefully. More generally, where one alternative plainly risks irreversible effects on the child that are bad and the other does not, there is no need to make longer-term predictions or more complicated psychological evaluations of what is likely to happen to the child's personality.

But to be easy, a case must involve only one claimant who is well known to the child and whose conduct does not endanger the child. If there are two such claimants or none, difficult choices remain. Most custody disputes pose difficult choices. In child-neglect cases, for example, the existing home may clearly be far from "optimal," but placing the child with a foster family unknown to the child poses serious risks as well. ${ }^{171}$ Without knowing the longterm effects of foster care on children, for example, how is the judge to decide in all but the most obvious cases whether a four-year-old child is better

171. See text at notes 199-204 infra. 
off removed from the parental custody of neglectful parents whose conduct does not endanger the child's physical health? And in many private disputes, the court must often choose between parties who each offer advantages and disadvantages, knowing that to deprive the child completely of either relationship will be disruptive. In a divorce custody fight, for example, where the mother is overprotective, possessive, and insecure and the father is demanding, aggressive, and hard-driving, how is the judge to decide where to place a seven-year-old child?

\section{III}

\section{IMPLICATIONS OF INDETERMINACY}

\section{A. Would Rules Be Better?}

Custody disputes are now decided on the basis of broad, person-oriented principles that ask for highly individualized determinations. The trial judge has broad discretion, but the question asked often has no meaningful answer. What are some of the implications of the use of indeterminate standards in custody disputes? Would more precise standards that ask an answerable question be better? As Professors Hart and Sacks have noted, even where a general standard is "avowedly indeterminate," a legislature or court may develop "subsidiary guides" that "take the form both of more nearly precise principles and policies ... and of specific rules and standards." ${ }^{172}$ Indeed, a normal element of the adjudicatory process is the formulation of intermediate premises or rules that are then tested and elaborated by application in individual cases. ${ }^{173}$

More rule-like standards would avoid or mitigate some obvious disadvantages of adjudication by an indeterminate principle. For one thing, the use of an indeterminate standard makes the outcome of litigation difficult to predict. This may encourage more litigation than would a standard that made the outcome of more cases predictable. Because each divorcing parent can often make plausible arguments why a child would be better off with him or her, a best-interests standard probably creates a greater incentive to litigate than would a rule that children should go to the parent of the same sex. Similarly, a broad, individualized child-neglect standard that gives very great discretion to a juvenile court to remove a child from parental custody, may encourage social workers, probation officers, and other state officials to seek intervention in a broader range of cases than might a narrow standard.

An indeterminate standard raises a number of questions related to fairness that better defined and less discretionary standards could minimize. Inherent in the application of a broad, person-oriented principle is the risk of retroac-

172. H. Hart \& A. Sacks supra note 20, at 169-70.

173. See id. at 168-71. See also notes 20-21 supra. 
tive application of a norm of which the parties affected will have had no advance notice. This may be unfair because ( 1 ) the private parties may have no opportunity to conform their private conduct to the norm subsequently applied by a particular judge; and (2) during the litigation itself, a party may not have an opportunity to address or question the aspect of the case that the court uses as a basis for decision. ${ }^{174}$

Indeterminate standards also pose an obviously greater risk of violating the fundamental precept that like cases should be decided alike. ${ }^{175}$ Because people differ and no two custody cases are exactly alike, the claim can be made that no process is more fair than one requiring resolution by a highly individualized, person-oriented standard. But with an indeterminate standard, the same case presented to different judges may easily result in different decisions. ${ }^{176}$ The use of an indeterminate standard means that state officials may decide on the basis of unarticulated (perhaps even unconscious) predictions and preferences that could be questioned if expressed. Because of the scope of discretion under such a standard, there is a substantial risk that decisions will be made on the basis of values not widely shared in our society, even among judges.

A simulation study that analyzed the factors influencing the decision whether to provide a child with certain services within the child's own home or instead remove the child to foster care demonstrates the risks of a broadly discretionary standard. ${ }^{177}$ In this study, three child welfare professionals, each with at least five years' experience, were independently given the actual files for ninety-four children from fifty families. Each was asked to decide whether the child should be removed from parental custody and put into foster care or whether, instead, services should be provided within the home. The three agreed in less than one-half of the cases (forty-five out of ninety-four). Even more significantly, when each was asked to indicate the factors influencing the decision, the study concluded, "even in cases in which they agreed on the decision, [they] did not identify the same factors as determinate." 178

This analysis shows the importance of who has the authority to decide what is best for a particular child, and under what circumstances. Today, custody disputes are ultimately assigned to courts for resolution, suggesting that a trial judge has the primary authority to decide, although it is not clear how decision-making responsibility is in fact shared by the trial judge with various other professionals (social workers, psychologists, psychiatrists) who also par-

174. See L. Fuller, The Morality of Law $51-62$ (rev. ed. 1969).

175. See,e.g., J. Rawls, A Theory of Justice 237 (1971).

176. $C f$. H. Kalven \& H. Zeisel, The American Jury (1966), which suggests that particular judges, jurors, and lawyers do not significantly affect the outcome of torts cases.

177. See M. Phillips, A. Shyne, E. Sherman, \& B. Haring, Factors Associated with Placement Decisions in Child Welfare $69-84$ (1971).

178. Id. at 84 . 
ticipate in the process. ${ }^{179}$ Implicit in some suggested reforms is the notion that the power to decide should be shifted from the judge to some other state official with different professional training. ${ }^{180}$ While judges may be illequipped to develop and evaluate information about the child, ${ }^{181}$ having some other state official decide or making various procedural adjustments (such as giving counsel to the child, providing better staff to courts, or making the proceedings more or less formal) will not cure the root problem. The indeterminacy flows from our inability to predict accurately human behavior and from a lack of social consensus about the values that should inform the decision. Procedural adjustments may make the system fairer and more efficient and may avoid some conspicuously erroneous determinations-goals worth pursuing. But neither greater use of existing expertise nor better procedures will make an indeterminate question answerable for an individual case.

Unlike procedural changes, adjudication by a more determinate rule would confront the fundamental problems posed by an indeterminate principle. But the choice between indeterminate standards and more precise rules poses a profound dilemma. The absence of rules removes the special burdens of justification and formulation of standards characteristic of adjudication. Unfairness and adverse consequences can result. And yet, rules that relate past events or conduct to legal consequences may themselves create substantial difficulties in the custody area. Our inadequate knowledge about human behavior and our inability to generalize confidently about the relationship between past events or conduct and future behavior make the formulation of rules especially problematic. Moreover, the very lack of consensus about values that makes the best-interests standard indeterminate may also make the formulation of rules inappropriate: a legal rule must, after all, reflect some social value or values. An overly ambitious and indeterminate principle may result in fewer decisions that reflect what is known to be desirable. But rules may result in some conspicuously bad decisions that could be avoided by a more discretionary standard. What balance should be struck?

Three assumptions guide what follows. First, family autonomy is given a high value. ${ }^{182}$ Second, continuity and stability in relationships are assumed to

179. For the foster-care system now, it might be argued that the social workers, probation officers, psychologists, and psychiatrists involved in the process are the ones who actually decide when children should be removed from parental custody or kept in foster care. In my study of the annual review process, the judges nearly always followed the social worker's recommendation. But deciding the direction of the causal link is no easy matter, since social workers are sometimes known to shape their recommendations according to what they think a particular judge will want to decide.

180. See, e.g., Watson, supra note 5, at 79; Hall, Family Law: Arrangements for the Care and Upbringing of Children (Sec. 33 of the Matrimonial Causes Act 1965), in 2 London Law Commission 39-40 (1968).

181. See sources cited in note 15 supra.

182. See text at notes $185-90$ infra. 
be important and desirable for children, especially for young children. This proposition cannot be proven beyond any doubt by existing empirical studies, and accurate predictions for a particular child about the effects of the lack of stability are beyond existing techniques. But a substantial and impressive consensus exists among psychologists and psychiatrists that disruption of the parent-child relationship carries significant risks. ${ }^{183}$ Third, legal rules, especially in an area touching upon substantial intrafamilial relationships, should not contradict deeply held and widely shared social values.

The possibilities for more determinate custody standards are explored separately for the two judicial functions because different considerations inform each. The scope of the child-protection function poses a fundamental question about the distribution of power between the family and the state. ${ }^{184}$ A legal standard for child protection must be evaluated by its capacity to identify and distinguish those cases where the state should intrude coercively on family autonomy. Moreover, the child-protection function is usually performed within the context of a complicated social welfare bureaucracy of which the court is only a part. The legal standards for child protection must be judged by how well they make the bureaucracy purposeful and accountable. Legal standards for private dispute settlement, on the other hand, neither allocate power between the family and the state nor regulate a bureaucracy responsible for the primary care of children. Instead, the evaluation of private-dispute-settlement standards centers on how fairly and efficiently they guide authoritative judicial resolution of a dispute private individuals were unable to decide for themselves.

An important distinction between the two functions is their relation to the distribution of power between the family and the state. Legal standards for private dispute settlement guide judicial resolution of a private controversy. In this instance, authoritative resolution does not in itself expand the state's role with regard to child rearing. Legal standards for the child-protection function, on the other hand, act both to define when government may intrude into the family and to control child rearing through coercion. Defining the appropriate scope of the child-protection function is therefore necessarily related to profound questions of political and moral philosophy concerning the proper relationship of children to their family, and the family to the state.

Like the choice in the judicial system of which party is to bear the burden of proof (or the risk of nonpersuasion), one's starting point as to the proper distribution of power can profoundly affect policy conclusions, particularly in the face of factual uncertainties and value clashes. Broadly speaking, there are

183. See, e.g., J. Bowlby, Maternal Care and Mental Health (Who Monograph No. 2, 1952); A. Freud \& D. Burlingham, Infants Without Families: The Case for and Against Residential Nurseries (1944); Napier, Success and Failure in Foster Care, 2 Brit. J. Soc. Work 187 (1972); Ellsworth \& Levy, supra note 6.

184. See text at part 111, B, l(a) infra. 
three basic "starting points" for analyzing policies concerning children: (1) state paternalism, which assumes that the state has primary responsibility for children and ought to exercise full control over their lives, except where delegation to the family is justified; (2) family autonomy, which assumes that power and responsibility for children generally ought to be vested in private hands-essentially the family-except for cases where government rule can be justified; and (3) agnosticism, which rests on no preference and instead approaches individual policy issues on their own merits.

No single starting point is an imperative for all organized societies. Assumptions about the appropriate division of responsibility between the family and the state may change over time. Child rearing practices in other societies appear to allocate much greater power and responsibility to the community or the state and to institutions such as the church, and considerably less to the nuclear family. ${ }^{185}$ In our own society, power over children is shared by the state and the family, and the existence of compulsory education laws, child labor laws, and the juvenile court all show that the state imposes substantial legal constraints on the family. Particularly for the poor, government intrusion into family life strikes many as very significant. ${ }^{186}$

Much of this analysis of the judicial role in no way depends upon acceptance of a particular starting point, although I should make clear that my own preference is for family autonomy. Even if one assumes that the sole criterion for evaluating the three alternative starting points is the interest of the child, there are affirmative justifications for making the family the presumptive locus of decision-making authority, particularly if there is no social consensus about what is best for children. Within the family, the child is more likely to have a voice in the decision, even if his wishes may not be determinative. Family members are more likely to have direct knowledge about a particular child. Affection for the child and mutual self-interest of family members are more likely to inform decisions. In all events, the evaluation of judicial functions in child custody that follows does not require a choice between family autonomy and agnosticism. Some of the policy recommendations do reflect, however, my rejection of state paternalism as a starting point, and it is useful here briefly to summarize the reasons.

First, state paternalism seems inconsistent with our historical and constitutional traditions. Indeed, family autonomy-the notion that those wishing a broader role for coercive governmental intrusion into the family carry a heavy burden of proof-has been the traditional American assumption. ${ }^{187}$ Pierce $\%$.

185. See L. Minturn \& W. Lambert, Mothers of Six Cultures: Antecedents of ChildREARING (1964).

186. See sources cited in note 74 supra.

187. For an imaginative discussion of why the family should be the preferred locus of decision-making authority for a child's education and why a system of educational vouchers 
Society of Sisters, in which the Supreme Court struck down Oregon's attempt to compel attendance of children at public schools, may be viewed as a constitutionally-based limitation on state power to intrude into family decisionmaking. ${ }^{188}$ The high value placed upon family autonomy reflected in that decision suggests a consensus that government may act coercively only when good cause is shown. Such a position would be consistent with our national ideological preference for decentralized decision-making, as generally evidenced by our economic and political system.

Second, state paternalism seems inconsistent with the present distribution of authority and responsibility for children. Most American families today enjoy substantial autonomy with regard to child rearing, and this has important implications for defining the limits of the child-protection function in custody disputes. The responsibility and opportunity of custody is assigned to a child's natural parents, and for the overwhelming majority of children, this simple rule suffices. For only a comparatively small proportion of children must a court resolve a custody dispute and perform either the private dispute-settlement ${ }^{189}$ or child-protection function. ${ }^{190}$

Even if one were to accept paternalism as the starting point, broad definition of the child-protection function should be rejected because of its unfortunate consequences. What is best for children is often indeterminate; broad and discretionary standards for child-protection invite decisions based on the values of the particular judges and state officials responsible for a particular case. And apart from the internal integrity of the law, what has happened to

should therefore be adopted, see J. Coons \& S. Sugarman, Choice, Nov. 1975 (unpublished manuscript on file at School of Law, University of California, Berkeley).

188. 268 U.S. $510,534-35$ (1925).

189. Most divorces do not involve custody disputes requiring judicial resolution. The best known study of the extent to which divorced parents agree on custody arrangements involved a survey taken by Goode in 1948 of some 425 recently-divorced urban mothers. Eighty-four per cent of them responded "yes" to the question of whether the custody arrangements that had been made were agreeable to both parents. The author speculated that the paucity of contested cases might reflect the father's normal expectation and acceptance of the fact that the mother would be granted custody; and, indeed, his data showed that the mother had, in fact, been granted custody in about 95 per cent of the cases. See W. Goode, supra note 22, at 313. It is interesting to speculate whether and to what extent these figures would differ today. The prevailing social norm of maternal custody appears to be softening, and this is reflected in more neutral legal standards. See text at notes 42-44 supra. If so, it may be that fathers will assert competing claims with greater frequency and that this will lead to more custody contests. And perhaps nofault divorce will contribute to this trend as an outlet for anger. See Strauss \& Strauss, Book Review, 74 Colum. L. Rev. 996, 1003-04 (1974), citing Sass, The Iowa No-Fault Dissolution of Marriage Law in Action, 18 S.D.L. Rev. 629, 650, 652 (1973); M. WheEler, No-Fault Divorce 14 (1974), citing unspecified "studies" that have shown one out of three divorces involving children "is followed by still more litigation." While the proportion of contested custody cases has perhaps increased, I suspect that parents themselves still work out custody arrangements without resort to judicial resolution in most cases today. A recently begun empirical study of the effects of the changes to no-fault divorce in California offers substantial hope of shedding some light on these questions.

190. See Mnookin, supra note 4 , at 600. 
children involved in the foster-care system-where the state has primary responsibility for the care of some children-should give pause to those seeking broader state authority. Indeed, even if one assumes that the family is simply a convenient instrument for the exercise of state power, an understanding of limitations with regard to resources, official talent, and what is known about human behavior is essential to the analysis of the judicial role.

\section{B. The Child-Protection Function}

For child protection, the adverse consequences of indeterminate custody standards can be dramatically illustrated by an examination of what happens to children who have been coercively removed from parental custody and placed in foster care. The analysis of these consequences of indeterminacy has two parts: first, with regard to the decision to remove; and second, with regard to what happens to children after they are removed. For both, less ambitious and more determinate rules for child protection are needed.

\section{The Consequences of Indeterminacy}

a. Indeterminacy and the Decision to Remove

Existing legal standards provide little guidance for the identification of cases where state intervention to protect children is appropriate, giving broad discretion to the judge. There are four reasons why this is wrong.

(1) For child protection, unlike private dispute settlement, the use of an indeterminate standard is inconsistent with the proper allocation of responsibility between the family and the state. Implicitly, we have a shared assumption that the court's child-protection function is to enforce minimum social standards, not to intervene coercively in an attempt to do what is best or least detrimental. A simple hypothetical will illustrate the problem. Suppose there are two couples, the Smiths and the Joneses. The Smiths wish to adopt a child. The Joneses have a four-day-old baby daughter whom they wish to keep. What circumstances would allow a judge to conclude that it would be in the baby's "best interests" or would be "less detrimental" to remove the child from the Joneses and place it with the Smiths?

Suppose both Smith parents were well educated, wealthy, and healthy; loved children; and appeared to be highly successful parents with two older children. Suppose the Joneses were older; had no experience at child rearing; had severe financial problems; and Mr. Jones was in bad health. There are certainly plausible and perhaps even persuasive reasons to believe the child's "life chances" would be greater if placed with the Smiths. And yet, a decision to remove the daughter from the Joneses for placement with the Smiths would be considered by most in our society to be monstrously unjust. On the facts of the hypothetical, most judges and other state officials would no doubt refuse to remove. But the legal standards themselves, by asking an indetermi- 
nate and inappropriate question, invite an overly ambitious and inappropriate response.

(2) An indeterminate standard allows a court to evaluate parental attitudes and behavior on the basis of the judge's personal values. An indeterminate standard invites reliance by the judge on personal values, and this is especially risky when class differences confound the problem. Most foster children come from poor families. ${ }^{191}$ The foster-care system is frequently accused of being class-biased. ${ }^{192}$ Even though there are other plausible explanations for the high proportion of foster children from poor families, ${ }^{193}$ present-day juvenile court standards allow a judge to import his own personal values into the decision-making process and therefore leave considerable scope for class bias.

An examination of available cases dramatically illustrates how a judge's attitude toward child rearing, sexual mores, religion, or cleanliness can affect the result of court proceedings. These cases clearly reveal the risks of "individualized" decisions under vague judicial standards. ${ }^{194}$ In recent years, there have been several appellate court decisions ${ }^{195}$ rejecting extreme attempts by

191. See, e.g., sources cited in note 74 supra.

192. See, e.g., Rein, Nutt, \& Weiss, supra note 74. See also S. Katz, supra note 68, at 91.

193. The condition of poverty may lead to family breakdown and to a greater likelihood that children will be endangered in times of crisis. Alternatively, since poor families are more subject to public scrutiny (by social workers who administer welfare programs), their faults, even if not unusual, may be more conspicuous than would otherwise be the case. Finally, since poor families have access to few resources in the event of family crisis, their children may be forced into the foster-care system because other forms of substitute care-such as babysitters, relatives, and daycare centers-are not available. See Rein, Nutt, \& Weiss, supra note 74.

194. In deciding whether to remove a child from parental custody, various judges have thought it relevant that a mother had extramarital sexual relations, see, e.g., In re Booth, 253 Minn. 395, 91 N.W.2d 9.21 (1958); was a lesbian, see In re Tammy F., Civil No. 32643 (Cal. Ct. App. 1973); or had several illegitimate children. See, e.g., In re Three Minors, 50 Wash. 2d 653, 314 P.2d 423 (1957); In re Fish, 288 Minn. 512, 179 N.W.2d 175 (1970). Religious fanaticism and unconventional beliefs of a parent have, like sex, similarly triggered strong responses from some judges. See, e.g., In re Watson, 95 N.Y.S.2d 798 (Dom. Rel. Ct. 1950). And finally, there are cases where a child has been removed from parental custody because the physical conditions in the home have been seen as unsuitable for him. Thus, in a California case, an appellate court affirmed a juvenile court decision removing children from a dirty home. Although the parents claimed there was no evidence showing that the children had been harmed, the court maintained that the state

was not required, as appellants assert, to prove that the conditions of the above cause

"sickness and disease of mind or body" in order to establish "neglect". . . [T] [Te welfare

of the child is of paramount concern, and a purpose of the juvenile court law is to secure for each minor such care and guidance as will serve the spiritual, emotional, mental, and physical welfare of the minor and the best interests of the state.

In re Deborah Gibson, Civil No. 40391 (Cal. Ct. App., filed June 29, 1973). See also In re Jeannie Q, 32 Cal. App. 3d 288, 107 Cal. Rptr. 646 (1973). Some "dirty homes" may seriously endanger a child's growth and well-being, but many may merely offend middle class norms of cleanliness that both economic and cultural circumstances render both unfair and inappropriate. See Paulsen, Juvenile Courts, Family Courts, and the Poor Man, 54 Calif. L. Rev. 694 (1966). See generally Sullivan, Child Neglect: The Environmental Aspects, 29 Оноо Sт. L.J. 85 (1968).

195. See, e.g., In re Raya, 255 Cal. App. 2d 260, 63 Cal. Rptr. 252 (1967) (reversing neglect determination premised only on fact that the parents were living unmarried, with new partners, because unable to afford divorce); State v. Greer, 311 S.W.2d 49, 52 (Mo. Ct. App. 1958) (reversing juvenile court decision to remove baby who was "concededly adequately housed, fed, clothed 
trial court judges to use neglect laws "to impose middle-class mores upon families and to punish a parent's undesirable conduct unless that conduct can be shown to result in damage to the child."196 For two reasons, however, these cases do not significantly limit the discretion of the judge who hears the case. First, the appellate decisions suggesting that specific factors are not appropriate for consideration also emphasize the continuing need for individualized determinations and wide latitude for trial judges. ${ }^{197}$ Second, juvenile court judges can often disguise a decision based on an "improper" factor by vague recitation of general language: the real reasons may be very different from the stated ones. ${ }^{198}$

(3) Courts may underestimate the risks of removal. In a neglect proceeding, the disadvantages of leaving a child at home often seem compelling. Because the judge is often unaware of or unable to evaluate the psychological risks of foster care, an individualized determination under an indeterminate standard may be biased in favor of removal. There is evidence that children in foster care experience higher rates of psychological disturbance than children generally. ${ }^{199}$ Although it cannot be demonstrated that placement in foster care created these problems, placement may carry substantial risks for several reasons. First, the initial separation in itself may be psychologically damaging to the child. ${ }^{200}$ Second, the ambiguous and anomalous position of a foster

and attended, personally and medically" simply on ground that mother had, on occasion, visited taverns, been arrested for reckless driving, and had the child out of wedlock).

196. S. KATz, supra note 68 , at 69.

197. See In re A.J., 274 Cal. App. 2d 199, 78 Cal. Rptr. 880 (1969).

198. David Matza thought individual treatment in juvenile court dispositions was a "mystification," and his observations have relevance to the best-interests standard:

To the extent that it prevails, its function is to obscure the process of decision and disposition rather than to enlighten it. The principle of individualized justice results in a frame of relevance that is so large, so all-inclusive, that any relation between the criteria of judgment and the disposition remains obscure.

D. Matza, Delinquency and Drift 115 (1964).

199. See The Community's Children: Long-Term Substitute Care: A Guide for the Intelligent Layman (J. Parfit ed. 1967); G. Trasler, In Place of Parents: A Study of Foster Care (1960); E. Weinstein, The Self-Image of the Foster Child (1960); Eisenberg, The Sins of the Fathers: Urban Decay and Social Pathology, 32 Aм. J. Orthopsychiatry 14 (1962); Maas, Highlight of the Foster Care Project: Introduction, 38 Child Welfare 5 (July 1959).

200. Because of the effects of "separation trauma," some psychologists argued that the act of removal may be harmful. See Glickman, Treatment of the Child and Family After Placement, 28 SoCIAL Services Rev. 279 (1954); Young, Placement From the Child's Viewpoint, 31 Social Casework 250 (1950). See also J. Bowlby, supra note 183; N. Littner, Some Traumatic Effects of Separation and Placement (1956). Some psychologists have since modified this position, arguing that children who remain in their homes with neglectful or indifferent mothers may experience greater psychological harm than do children in foster homes. See, e.g., L. Casler, Maternal Deprivation: A Critical Review of the Literature (Society for Research in Child Development, Monograph No. 26, 1961); M. Ainsworth, Deprivation of Maternal Care: A Reassessment of its Effects (WHO Public Health Papers No. 14, 1962); A. Freud \& D. Burlingham, supra note 183. Much of the early "separation" literature was addressed to the question of institutionalizing children-especially infants. The maternal-deprivation literature began focusing on the need for a continuous relationship with the child-caring person-whether 
child within a foster family may make it difficult for the child to develop an adequate conception of who he is, where he is, or why he is there-a situation that may have detrimental psychological effects. ${ }^{201}$ And third, the instability of the foster-care system itself-the rapid turnover of social workers and judges-may be damaging to the child..$^{202}$

Existing evidence does not allow confident evaluation of the frequency or the severity of the psychological harm that may be caused by placement in foster care. Even less does it allow the comparison of such risks of removal with those of remaining at home. Analysis of the differential effects of foster placement on a child's development raises severe methodological problems for the social scientist. These include defining a control group, establishing a standard of "successful development," and isolating the factors responsible for

at home, in an institution, or in a foster home. When researchers observed the effects of separation on older children, concern was again expressed about the risks of removing a child for placement in foster care. See R. Dinnage \& M. Pringle, Foster Home Care, Facts and Fallacies: A Review of Research in the United States, Western Europe, Israel and Great Britain Between 1948 and 1966 (1967); M. Wolins \& I. Pillavin, Institution or foster Family: A Century of Debate (1964).

201. "Family life can be complex indeed for the foster child." E. Weinstern, supra note 199, at 47. The child often experiences conflict over which set of parents, natural or foster, to trust and rely on when in trouble. Moreover, the child may observe power struggles among the natural and foster parents, the social workers, and the judge, each of whom has a reason to be concerned about the child's care and future. A foster home is supposed to provide, insofar as possible, a normal family environment. But agencies often become concerned if the foster parents grow too attached to a child. In one case, the highest state court in New York approved the transfer of a child from a foster home to an unknown alternative because the foster parents "had become too emotionally involved with the child." In re Jewish Child Care Ass'n, 5 N.Y.2d 222, 226, 156 N.E.2d 700, 702, 183 N.Y.S.2d 65, 68 (1959). The court upheld an agency determination "that the child's best interests necessitated her placement in another environment where she would not be torn between her loyalty to her mother and her boarding parents." Id. For some intriguing materials on this case, see J. Goldstein \& J. Katz, The Family and the Law: Problems for Decision in the Family Law Process 1027-34 (1965). Although the effects of ambiguous relationships are impossible to measure, there is a good theoretical argument and some suggestive evidence that a child's basic security and ability to form other relationships are shaken when he is torn by conflicting expectations and loyalties. See E. WeInstein, supra note 199, at 47-57, 66-70. Lack of a solid identity, which most children acquire largely in their relationship with their parents, perhaps causes the most harm. See generally J. Bowlby, Fortr-four Juvenile Thieves: Their Characters and Home-Life (1946), "Without an adequate conception of who he is, where he is, and why he is there, it is difficult to see how the foster child could develop well in a situation that is as complex and problematic as placement." E. WEINSTEIN, supra note 199, at 66.

202. Children are sometimes moved from home to home, and there is rapid turnover of social workers and judges involved in the case. See L. Costin, Child Welfare: Policies and Practice (1972); A. Kadushin, Child Welfare Services 420 (1967); Mnookin, supra note 4, at 625. Studies strongly indicate that personality problems are more frequent among children who have been moved often. See H. Maas \& R. Engler, Children in Need of Parents 389 (1959); Meier, Adults Who Were Foster Children, 13 Children 16 (1966). Maas and Engler, for example, conclude that "instability in relationships fosters personality disturbances." H. MAAS \& R. ENGLER, supra at 422 . On the other hand, the frequency of moves may depend on the child's adjustment before he even enters foster care: a disturbed child may be more likely to experience multiple placements, and his symptoms may increase accordingly. Whatever the reason, both former foster children and experienced social workers agree that moving a child from foster home to foster home is a painful and at times damaging experience. 
any noticeable effects. No studies prove that foster care either benefits or harms children. ${ }^{203}$ Since predictions of how an individual child will fare in foster care have not proved reliable, ${ }^{204}$ there is no reason to believe a judge can accurately assess the risks of placement.

(4) Present legal standards fail to require judicial evaluation of alternatives to removal. That foster care probably entails some risk of psychological harm does not imply that a legal standard should be adopted to make it impossible to take children from their parents and place them in foster care. But it does suggest that a child's life may not be improved by removal unless the dangers of remaining at home are immediate and substantial and there are no means of protecting the child within the home.

Placing a child away from home is often referred to as a "last resort," but most communities in fact offer few preventive or protective services for children within the home while a family is helped through a crisis. Day-care or baby-sitting services, along with parental counseling, might make removal unnecessary in a wide variety of circumstances; but such services typically are unavailable. ${ }^{205}$ Even when they are available, neglect statutes and the bestinterests standard do not require that before ordering removal, a court conduct an inquiry into whether the child can be protected if left in parental custody. ${ }^{206}$

203. The most famous longitudinal study, published in 1924, traces what happened to 910 former foster children who had spent one year or more in a foster home. The research question was: "Has the subject shown himself capable (or incapable) of managing himself and his affairs with ordinary prudence?" S. Thers, How Foster Children Turn Out 19 (1924). The results of the study showed 615 subjects ( 67.5 per cent) as "capable," 182 subjects (20 per cent) as "incapable," and 113 subjects (12.5 per cent) as of "unknown capability." Needless to say, criteria for success were defined in only the most vague and arbitrary terms. Moreover, one cannot judge whether these results were good or bad without a control group, and definition of such a group presents overwhelming problems. More recent studies have not been able to overcome the methodological difficulties nor provide definitive answers about the long-range effects of foster care. See McCord, McCord, \& Thurber, The Effects of Foster-Home Placement in the Prevention of Adult Antisocial Behavior, 34 Social Services Rev. 415 (1960), reporting a study that matched a group of nineteen boys placed as a last resort in foster care. Contrary to the initial hypothesis, the results showed that a significantly higher proportion of those who had been placed in foster homes had criminal records in adulthood. See also Meier, Current Circumstances of Former Foster Children, 44 ChILd Welfare 196 (1965), reporting a study in which eighty-two persons who had been in foster care for five years or more were interviewed and their "adjustment" evaluated. A higher than normal incidence of marital breakdown and a higher proportion of illegitimate offspring were found. On the other hand, one-half, of the group owned or were buying their own homes, few needed social services, and nearly all were self-supporting. See also Meier, supra note 202; Roe, The Adult Adjustment of Children of Alcoholic Parents Raised in Foster Homes, 5 J. STudies on Alcohol 378 (1944). Since 1964, a research group at Columbia University had been engaged in longitudinal research relating to foster care. Their data and conclusions have not yet been published.

204. Compare R. Parker, Decision in Child Care: A Study of Prediction in Fostering (1966), with Napier, Success and Failure in Foster Care, BRIT. J. Social WoRK 187 (1972).

205. See American Humane Association, Child Protective Services, A National Survey, Final RePORT 20 (1967); Paulsen, supra note 194; Mnookin, supra note 4, at 626-27.

206. See text at notes 67-84 supra. Minnesota is an exception, for its statute provides that a 
b. Children After Removal: the Limbo of Foster Care and Its Relationship to Indeterminate Legal Standards

An assessment of the risks involved in separating children from their parents requires explicit knowledge of the foster-care system. What happens to foster children? Are they happy while in foster care? What harm, both shortterm and long-term, can result from being put into this system? How many children "fail" in foster homes? In theory, "the distinguishing aspect of foster care is that it is designed to be a temporary arrangement. The family is broken up only so that it can be put together again in a way that is less problematic for the child." ${ }^{207}$ But existing evidence suggests that children removed by the state from the home of their parents are often destined to remain in limbo until adulthood, wards of a largely indifferent state. On the one hand, they frequently are unable to return to their natural parents, who usually have been offered no rehabilitative help. ${ }^{208}$ On the other hand, they are sometimes placed in a series of foster homes, with each family cautioned not to become too attached. Few foster children are ever adopted. ${ }^{209}$ Thus, a large proportion of those entering the system grow up without a permanent and secure home. The use of indeterminate legal standards contributes substantially to this failure of the foster-care system because they fail to require the juvenile court and the social-welfare bureaucracy to account for the children who have been removed from parental custody.

The existing legal framework for foster care does not prevent the convenience of the social-welfare system, rather than the interests of the child, from being the primary motivating factor. Social workers, their supervisors, and juvenile court judges lack the time and energy (given substantial case loads) to make careful individualized determinations of what would be best for a child. Instead, these state officials apply unarticulated rules of thumb. Many decisions are made because of organizational considerations having nothing to do with the interests of the child. ${ }^{210}$ In all events, because virtually

child may be removed from the parents "only when his welfare or safety and protection of the public cannot be adequately safeguarded without removal." Minn. STAT. ANN. \$260.011 (1971).

207. See A. Kadushin, supra note 202, at 411.

208. More than 70 percent of the fathers and mothers of the children in this study either had no relationship with the agencies responsible for the care of their children or their relationship was erratic or untrusting. In many instances the agencies' resources were such that their staff's time was entirely consumed with the day-to-day job of caring for the children. They had no time for the kind of continuous work with the parents of the children which could effect the rehabilitation of the home. Frequently agencies fail to appreciate the dynamics of intrafamily relationships as a whole and work only with the child.

H. MAAS \& R. ENGLeR, supra note 202, at 390-91.

209. See text at notes 217-19 infra; H. Jeter, Children, Problems and Services in Child Welfare Programs 87 (1963). This latter study anticipated only 12 per cent would return home. See also Lewis, Foster-Family Care: Has It Fulfilled Its Promise?, 355 Annals 31, 36 (1964); A. Gruber, Foster Home Care in Massachusetts 19 (1973).

210. Financial considerations, for example, can often result in a foster child being transferred 
any conclusion can often be justified under the vague rubric of best interests, there is no necessity for these officials to specify either their value judgments, their psychological hunches, or the organizational consideration underlying their rules of thumb.

These risks can be illustrated by the operation of the California system. There, as in many states, the juvenile court has a continuing responsibility for children after they are removed from parental custody and put into foster care $^{211}$ and is required to hold a regular hearing at least once a year to review what has happened to the child and what plans are being made for the future. $^{212}$ The social worker or probation officer responsible for the child is required by statute to make an investigation and file a supplemental report for this hearing. ${ }^{213}$ While the statutory provision provides no standard to be used by the court in determining what is to be done at these annual-review hearings, a recent California Supreme Court decision held that the court should retain jurisdiction "as long as the best interests of the minor so require." 214

Observation of this annual-review process belies any notion that careful individualized determinations are being made. For purposes of this article, every annual-review hearing was observed in a selected county during a onemonth period. ${ }^{215}$ The court reviewed 177 cases involving 321 children, 169 of whom were in foster care. ${ }^{216}$ Approximately two-thirds of these hearings took two minutes or less. Only 6 per cent took ten minutes or more, and the longest took twenty minutes.

Nearly all the cases were decided only on the basis of a two- or three-page written report by the social worker responsible for the case. A sample of written reports revealed that none specified what was being planned for the child between the current hearing and the next annual review or what the goals for that child were during the coming period. Instead, these reports simply reported what had happened to the child since the last review. The social worker who prepared the report appeared in about 12 per cent of the cases. In only 19 per cent of the cases did one or both natural parents appear for the hearing, although the statute required notice. A lawyer representing the

from one county to another, simply because the child's natural parent has moved. See J. Pers, supra note 69

211. See CAL. Welf. \& Inst'ns CODE $\$ \$ 600,725$ (West 1972).

212. See Cal. Welf. \& INST'NS Code $\$ 729$ (West 1972).

213. See id.

214. In re B.G., 11 Cal. 3d 679, 692, 523 P.2d 244, 252, 114 Cal, Rptr. 444, 452 (1974).

215. Michael Wald, of Stanford University, developed the questionnaire with me and administered the test in a second county; his results were completely consistent with those reported here. See M. Wald, State Care of Neglected and Dependent Children 1976 (manuscript to be published in Stanford Law Review).

216. Of these children, 132 were in foster family homes, 13 were in group homes, and 24 were in institutions. The remaining 152 children were dependents of the court but were living with their parents or with relatives at the time of the annual review hearings. 
natural parent appeared in only 7 of 177 cases. A foster parent was present in less than 5 per cent of the cases.

Most striking was the failure of this process to push cases either in the direction of returning the child to the home of the natural parents or to some other resolution that would provide continuity and stability. Of the 169 children in foster care before the hearing, over 90 per cent simply continued in such care. Only Il were returned home as a result of the hearing. Jurisdiction of the court was terminated because of adoption in only 4 of the 177 cases reviewed.

It is intriguing to consider why so few children placed in foster care are adopted. For a very substantial proportion of the children in care, there is little chance of returning to their natural parents. ${ }^{217}$

With this question in mind, I have studied the rather elaborate process by which foster children are considered for adoption in one California county. There the process works as follows. The social worker responsible for the child in the foster-care section must refer the case to the adoption section of the social welfare department. This requires sending the child's written file, together with a report, to the adoption section. A person in the adoption section will then investigate the child's circumstances and make an evaluation of whether an adoptive home can be found. If the adoption section chooses to proceed, it must then either secure the consent of the natural parent or file a petition for termination of parental rights. In 1972, the files for all the cases referred from foster care to the adoption section were examined. Eighty-five children from 65 families were referred, about 4 per cent of the average foster-care population during that year. After the initial referral, the adoption

217. On the basis of their analysis, Maas and Engler predicted that "better than half" of the more than 4,000 children they studied would be "living a major part of their childhood in foster families and institutions." H. MAas \& R. ENGLer, supra note 202, at 356. Similarly, in a study of 624 children under twelve who entered foster care during 1966 and were there at least 90 days, Fanshel found that 46 per cent were still in foster care three and one-half years later. See Fanshel, The Exit of Children From Foster Care: An Interim Research Report, 50 CHILd WELFARE 65 (1971). Wiltse and Gambrill recently examined a sample composed of 772 San Francisco foster children, about one-half of that city's entire caseload. They found that 62 per cent of them were expected to remain in foster care until maturity; the average length of time in foster care for all the children in their sample was nearly 5 years. See K. Wiltse, Decision-Making Processes in Foster Care 1974 (unpublished manuscript on file at School of Social Welfare, University of California, Berkeley). One juvenile judge has written about his surprise at the beginning of his term when he found that many of the neglected children under his jurisdiction had been in "temporary" foster care for five to six years. See Crary, Neglect, Red Tape and Adoption, 6 Nat'l Probation \& Parole Ass's J. 34 (1960). A recent study of foster care in Massachusetts provides shocking confirmation of foster-care limbo. Data were obtained on nearly every child in Massachusetts foster care on November 18, 1971. About 69 per cent of the children had been in foster care for 24 months or more. See A. Gruber, Foster Home Care in Massachusetts 28 (1973). Although less than 30 per cent of the children in foster care had parents who demonstrated interest in them, see id. at 18; few foster children were being considered for adoption by the social workers. See id. at 19. Social workers, asked why they considered children in foster care nonadoptable, commonly responded that the natural parents were still interested; but the study shows that the parents of one-half of these children in fact visited them once every two months or less. $I d$. at 20. 
section closed the cases of 19 children. Of the remaining children, the parents of 17 agreed to relinquish control, 2 children were declared orphans, and 40 petitions to terminate parental rights were filed, of which 38 were granted after a hearing.

While this analysis still must be preliminary, the evidence suggests that, with rare exceptions, adoption was considered and pursued only if there was no substantial chance that the natural parent would contest. This is plainly the case for the nineteen children whose parents consented to adoption. Of the forty cases in which termination proceedings were begun, with a single exception, abandonment was the only ground on which termination was sought, even though California law provides several other grounds. ${ }^{218}$ Moreover, the files suggest that in only eight of these termination proceedings did a parent or parents contest the petition at the hearing where the court ruled on the petition. ${ }^{219}$

The preliminary evidence also suggests that normally some dramatic event or external pressure was the cause of the initial referral from the foster-care worker to the adoption worker. The records indicate that about forty per cent of the referrals were made at the instigation of foster parents who wished to adopt. Others appeared to have been triggered by specific requests of some other person who wished to adopt the child, by the mother's death, or by other circumstances where it was very obvious that the parents wished to have nothing further to do with the child. Interestingly, twenty-five of the children referred were adopted by their foster parents.

The infrequent use of adoption cannot easily be justified on the grounds that what was done was best for each child. Adoption provides the child with greater security and stability than foster care. Moreover, the adoption of children in foster care would save the state a great deal of money by eliminating the need for payments to foster parents and reducing the number of social workers necessary to manage the smaller caseload. By examining the situation from the perspective of the individual social worker responsible for the foster child, however, the bureaucratic inertia is less surprising. The data from this study and my own observations are consistent with the theory that many social workers manage their case load in order to maximize "quiet cases"-where neither the child nor the foster parents are complaining to the social worker about the placement, and where the natural parent is not demanding services, asking for the child back, or causing trouble in any other way. To have a child adopted requires that the social worker prepare a report and refer the case to another section that makes an independent investigation. If adoption requires termination of parental rights, there will be a court hearing, and the

218. See, e.g., Cal. Civ. Code $\S 232(a)(2)$ (West Supp. 1975).

219. In six other cases, a parent made an appearance at an initial hearing, a continuance was granted, and the parent never appeared at subsequent hearings. 
social worker responsible for the child in foster care may be required to appear and be cross-examined by an attorney representing the natural parents. Many social workers are wary of courts and do not relish being part of the legal process. Moreover, the process of attempting to terminate parental rights will often generate hostility on the part of the natural parent who is not objecting to foster care and is unlikely in all events even to regain custody. Thus, instituting adoption both requires a substantial amount of work by the social worker and is often perceived as turning a case that was quiescent into a battleground. When one adds to all this a natural ambivalence about termination because of its dramatic and final quality, the infrequent use of adoption whenever a natural parent may object is not surprising. But the results can hardly be applauded from the child's perspective.

\section{The Quest for Rules for Child Protection in Custody Cases}

This discussion suggests that present indeterminate and discretionary standards for child protection (1) give government officials too much power to second-guess decisions ordinarily left to the family; (2) leave judges free to exaggerate the risks for children remaining in parental custody and to underestimate the risks of foster-care placement; (3) allow removal under circumstances where the child might be protected within the home; and (4) fail to require that the social-welfare bureaucracy and the juvenile court make adequate plans for children who are in the foster-care system. Legal standards both less ambitious and more determinate than the "best-interests-of-thechild" can correct some of these deficiencies.

Any new standards will necessarily be premised upon values that can be questioned and attacked and upon behavioral assumptions about the realities and effects of the present foster-care system. New research may demonstrate that some of these factual and behavioral assumptions are incorrect. But one advantage of more sharply defined legal standards is that they expose to analysis what is hidden behind the "best-interests" shield. The direction of change that $I$ think appropriate can be discerned from my earlier article ${ }^{220}$ and from some proposed California legislation based in part on it. ${ }^{221}$ Without spelling out all the details here, the outlines of the proposed reform can serve to illustrate the important themes.

a. Standards for the Decision to Remove

Judicial discretion for the child-protection function should be made much more limited. To the extent possible, the standard should be made more ob-

220. See Mnookin, supra note 4.

221. S.B. 30, Calif. Legis. Dec. 2, 1974, In a soon-to-be-published article, Michael Wald spells out in some detail a plan for statutory reform consistent with the suggestions made here. See M. Wald, supra note 215 . 
jective and determinate. The following standard would represent a move in the right direction:

A state may remove a child from parental custody without parental consent only if the state first proves: (a) there is an immediate and substantial danger to the child's health; and (b) there are no reasonable means acceptable to the parents by which the state can protect the child's health without removing the child from parental custody.

This standard is meant for the dispositional phase of a juvenile court proceeding where the state is asking that the child be initially removed from parental custody and placed in foster care.

Unlike the standards now used for neglect cases, this proposal would take the courts away from evaluating parental morality or sexual conduct, except in the rare cases when the child's health is endangered. The test would also focus judicial inquiry on whether the child could be protected within the home. A dirty-home case would no longer justify removal, because the state could usually protect the child by sending in a homemaker or housekeeper. Similarly, a child who is malnourished because the mother did not know anything about nutritional needs could be protected by either having a social worker teach the mother about nutrition or having someone sent into the home to prepare the child's meals.

The trial judge's role under the proposed standard still would not be easy. Judges would face the problem of predicting when the risks to the child were so great that the stricter standard for removal would be met. The terms "immediate" and "substantial" are not self-defining and would require interpretation. Nevertheless, the proposed standard is much more restrictive than existing standards. As stated by Ernst Freund: ${ }^{222}$

[I]n the absence of scientific certainty it must be borne in mind that the farther back from the point of imminent danger the law draws the safety line of police regulation, so much the greater is the possibility that legislative interference is unwarranted.

When there is an immediate and substantial danger to a child's physical health and the child cannot be protected at home, it is reasonable to predict that his or her lot will be improved by placement in foster care. Foster care does a reasonable job of protecting a child's physical health. But there is good reason to be concerned about a child's emotional health as well, and it is extraordinarily difficult to predict when a child is emotionally endangered. Moreover, there is no evidence whatsoever that foster care is psychologically therapeutic. There is therefore reason for concern that individualized determinations requiring predictions of future emotional harm to the child could, on balance, do more harm than good by introducing a highly speculative ele-

222. E. Freund, Standards of American legislation 83 (2d ed. 1965). 
ment into the process. On balance, "health" should be limited to "physical health."223

Another policy problem associated with the new standard relates to the question of how far a state must go in order to demonstrate that alternatives to removal will not work. The economic questions here are not trivial. For example, what if the means of protecting the child in the home are unduly expensive? In a dirty-home case, what if a child could be protected only if a full-time maid were available in the house? The word "reasonable" allows the court to take into account the costs of alternatives and to consider the economic question in the context of a specific case. ${ }^{24}$

Within the context of these new standards, additional procedural safeguards for juvenile-neglect cases might take on real meaning. Requiring the trial judge to specify in some detail the factual grounds underlying his decision would make appellate review of the initial determination more meaningful than it is now. The legislation proposed in California would require the court to specify the basis for concluding that there was a substantial and immediate danger and give an explanation of why less drastic means of intervention were found inadequate for the child's protection. Although appellate courts would not often second-guess a judge's conclusions about a witness's credibility, review could serve an important role in defining how much danger was sufficient to justify intervention and how far the state should go in providing alternatives.

223. The proposed California legislation would allow removal where:

The minor is suffering severe emotional damage indicated by extreme anxiety, depression, or untoward aggressive behavior against others and there are no reasonable means acceptable to the minor's parents or guardians by which the minor's emotional health may be protected without removing the minor from his parents' or guardians' physical custody.

S.B. 30, Calif. Legis. $\$ 726.5$ (b)3, Dec. 2, 1974, as amended, June 18, 1975.

224. The economic questions here are not trivial. For example, what if the means of protecting the child in the home are unduly expensive? In a dirty-home case, what if a child could be protected only if a full-time maid were available in the house? The word "reasonable" allows the court to take into account the costs of alternatives and to consider the economic question in the context of a specific case. Two general observations are in order: (1) The costs of foster care are substantial, always several thousand dollars per year. See D. Fanshel \& E. Shinn, Dollars and Sense in the Foster Care of Children: A Look at Cost Factors (1972); (2) Any method of protecting the child within the home that costs less than foster care almost always would be reasonable. Further, it would not be reasonable for a state to allow the level of resources available for home-based services to vary substantially among local jurisdictions merely because their capacity to raise revenue differs.

One clear goal of the new standard is to require states to devote more resources to the protection of children within the home. It is important that certain types of services-such as homemakers, housekeepers, and public health nurses-be available. But one unintended consequence of the proposed standard might be that the state would neither provide services to protect children within their homes nor remove children when they are in danger. If this were the state's response, the situation might end up worse than it is today. Children who need protection would be left in danger. Fortunately, this response is unlikely, both because of public concern about children and because of the vested political interest of the existing social welfare bureaucracy. 
b. Standards to Guide the Operation of the Foster-Care System After Removal

Even with the stricter standard, it is plain that some children will necessarily be removed from parental custody for placement in foster care. For these children, the critical question is how a legal framework might be developed to provide the maximum opportunity for continuity and stability for children who must be placed in foster care but who do not yet have psychological ties with their foster parents. Goldstein, Freud, and Solnit make clear that they would seek to protect a new psychological tie between a child and the foster parents once it is formed. But they do not answer the difficult questions about public policy: When should the state's purpose be to encourage the development of new ties for the child rather than the reunion of the child with his natural parents? Should visits by biological parents be controlled by the foster parents to encourage the growth of new ties? When should termination of parental rights and adoption be considered? Who should decide? By what criteria?

Flexible, discretionary, and indeterminate standards do nothing to require the juvenile courts and the social welfare bureaucracy to face up to these hard questions in a systematic way. The result in many ways is the worst of all worlds: children are removed too quickly; and once removed, little is done to maintain their ties with their natural parents or with parent substitutes. Rules could help achieve the principal objective of providing a greater degree of stability and continuity for children in the foster-care system.

The most direct way of doing this would be to require the judge at the end of a fixed period of time to proceed on the assumption that the child will not be returned to his natural parents and that the primary role of the state is to find an adoptive home or some other stable, long-term environment. The law should be changed to provide final termination of parental rights at the end of the required period if the child could not be safely returned to the home and if the state had made reasonable efforts to rehabilitate the parents while the child was living away from home. ${ }^{25}$ Different time limits are, of course, possible for different kinds of cases. ${ }^{26}$ Future research might show that rehabilitative prognosis of the family in certain identifiable types of cases is sufficiently poor to allow a quick decision. But a fixed time limit should be established at the time of removal on the basis of criteria that could be consistently and fairly applied.

At the time of the initial removal, the social-welfare department should be required to outline to the court the services that would be made available to the parents to correct the deficiency that required removal in the first place. A court hearing might be required every three months during the in-

225. See S.B. 30, Calif. Legis. § 232, Dec. 2, 1974, as amended, June 18, 1975.

226. See id. $\$ 729.5$. 
terim period to insure that the social-welfare department reported on its efforts and its results. The state should carry the burden at these hearings to show that the child could not be safely returned to the home. If the child could not safely be returned home at the end of the fixed statutory period, adoption would be the favored alternative. ${ }^{227}$ Some foster children would be difficult to place for adoption because of age, health, or behavior. Subsidized adoption would be an appropriate way to expand these possibilities. Short of adoption, other alternatives such as guardianship should be considered. In no event should the child be removed from foster parents who wish to make a long-term commitment to the child, provided the child has a substantial psychological relationship with the foster parents.

A fixed time period is necessarily arbitrary; a slightly longer or shorter period might be better for a particular case. Inevitably, some parents' rights will be finally terminated, even though with more time they might have been able to pull themselves and their families together. Some children may be left in foster care for the statutory period, even though termination at an earlier time would have been preferable. In theory, a flexible approach leaves room on an individual basis for fine discrimination. Goldstein, Freud, and Solnit appear to oppose "rigid statutory timetables." But flexible, discretionary standards in the context of social-welfare bureaucracy and juvenile courts will too often result in children being left in limbo for years because of repeated routine extensions, even though it is improbable that the child will ever go home.

\section{Private-Dispute-Settlement Function}

As earlier noted, the definition of standards for the private-disputesettlement function, unlike the child-protection function, does not pose a fundamental question about the distribution of power between the family and the state. Instead, the legal standards guide judicial resolution of a private

227. See id. \$ 729.5. The proposed California legislation requires the juvenile court at the end of the fixed period of time to order the social welfare department to investigate the opportunity of finding adoptive parents, legal guardians, or stable long-term foster-care placement for the child. If adoption is possible, the court is required to order the state to initiate termination proceedings unless:

(a) the parents or guardians have maintained a close family relationship with the minor through regular visitation and contact and the minor would benefit from a continuing relationship with them; or (b) a minor 14 years or older objects to termination of parental rights; or (c) the minor's foster parents are unable to adopt the child but are willing and capable of providing the minor with a stable and permanent environment and the removal of the minor from the custody of his foster parents would be seriously detrimental to the emotional well-being of the minor if the minor has substantial psychological ties to them.

Id. If any of these three exceptions apply, the court is then required to determine whether a legal guardianship is possible, and if it is not, then to require the department to facilitate a fostercare placement of the child in an environment that can be reasonably expected to be stable and permanent. Id. 
controversy. The use of an indeterminate standard for private dispute resolution does raise a number of questions related to fairness. ${ }^{228}$ In addition, the best-interests test probably encourages the judicial delay and lack of finality that plague custody law. Given a hopelessly ambitious standard that asks the impossible, judges may seek to avoid making an initial determination in a private custody dispute and may be more willing later to reopen and reconsider an initial decision. ${ }^{229}$ Finally, the use of an indeterminate standard for adjudication may result in more cases being litigated than would be true if more rule-like standards governed custody disputes requiring the privatedispute-settlement function. Because of these various disadvantages of an indeterminate standard, the analysis of more precise alternatives would seem very much in order.

This section begins with an exploratory search for more rule-like standards for the adjudication of private custody disputes. Apart from three intermediate rules that will help dispose of only a small number of cases, this safari returns with no game worth keeping. The quest continues by examining alternative methods of dispute resolution: mediation, informal adjudication, and random selection. My conclusion is hardly comforting: while the indeterminate best-interests standard may not be good, there is no available alternative that is plainly less detrimental.

\section{The Quest for Intermediate Premises}

Three intermediate rules seem justifiable for private dispute settlement. First, custody should never be awarded to a claimant whose limitations or conduct would endanger the health of the child under the minimum standards for child protection described above. The correct resolution of a private dispute is obvious where one claimant poses an immediate and substantial threat to the child's physical health and the other does not. ${ }^{230}$ Second, the court should prefer a psychological parent (i.e., an adult who has a psychological relationship with the child from the child's perspective) over any claimant (including a natural parent) who, from the child's perspective, is not a psychological parent. To award custody to a person who is a "stranger" to the child would unnecessarily risk harming the child where the other claimant has, on a continuing, day-to-day basis, fulfilled "the child's psychological needs for a parent as well as his physical needs." ${ }^{231}$ Third, subject to the two

228. See text at notes 174-76 supra.

229. The tradition that a court has continuing jurisdiction over the child following a divorce custody determination coupled with overly broad powers to modify initial decrees and interstate conflicts questions contribute to the possibility of reconsideration and modification of an initial determination. All of these practices have been criticized. See, e.g., Bodenheimer, The Rights of Children and the Crisis in Custody Litigation: Modification of Custody in and Out of State, 4 Colo. L. Rev. 495 (1975); see Golostein, Freud, \& Solnit 37.

230. See text at part II, B, 3 supra.

231. Goldstein. Freud, \& Solnit 98. 
rules noted above, natural parents should be preferred over others. In a dispute where the natural parent poses no danger to the child's physical health and is viewed by the child as his psychological parent, a preference for the natural parent over a third party gives expression to broadly shared social values about parental responsibilities for the welfare of their offspring and reflects the importance to the child of a sense of lineage. ${ }^{232}$

These three standards could be even-handedly and fairly applied, are consistent with the best-interests-of-the-child principle, and would dispose of some cases. For example, in a custody dispute between two parents where one posed a substantial danger to the child's physical health and the other did not, the first standard would be dispositive. And in disputes between a natural parent and a third party, the second and third standards would require that the natural parent prevail unless the third party had a substantial psychological relationship with the child from the child's perspective and the natural parent did not. Thus, in a case like Painter $v$. Bannister, ${ }^{233}$ where both the father and the child's grandparents had a substantial psychological relationship to the child, the father would prevail. In a case like In re B.G., however, the second standard would suggest that the foster parents would prevail over the natural mother, who appeared to be a psychological stranger to the children. ${ }^{234}$ These three standards would not, however, dispose of a very large class of private disputes: controversies between two natural parents, neither of whom would endanger a child's physical health, where both are psychological parents. ${ }^{235}$

For these disputes between parents, should additional rules be adopted? Alternative standards include awarding custody (1) on the basis of the sex of the parent (e.g., maternal preference) ${ }^{\mathbf{2 3 6}}$ (2) to the parent of the same sex as the child; ${ }^{237}$ (3) to the richer parent; (4) to the parent who would spend more time with the child; (5) to the parent chosen by the child $;^{238}$ or (6) to the parent whose psychological relationship with the child would be "less detrimental." 239 None of these seems preferable to the best-interests standard.

232. See, e.g., In re Guardianship of Smith, 42 Cal. 2d 91, 94, 265 P.2d 888, 891 (1954); Johnson v. Kelly, 44 Ga. 485, 487-88 (1871). See also R. Levy, supra note 4, at 337-45. The felt need of some adopted children to search out their natural parents is a useful reminder of the psychological importance of lineage. See B. Lifton, Twice Born (1975).

233. 140 N.W.2d 151 (Iowa 1966). See generally sources cited in note l supra.

234. 11 Cal. 2d 679, 699, 523 P.2d 244, 258, 114 Cal. Rptr. 444, 458 (1974). See text at notes 113-25 supra.

235. Another smaller class of unresolved cases are those where neither of the disputants is a natural parent and the first two rules are not dispositive. Disputes in guardianship proceedings may often fall into this class. In all events, the same sorts of additional rules could be specified.

236. See, e.g., note 42 supra; R. Levy, supra note 4, at 224-25 (recommending a presumption that the wife is entitled to custody).

237. See, e.g., statutes cited in note 43 supra.

238. See Note, Adoption Law Reform, 19 ME. L. REv. 290, 303.

239. See Goldstein, Freud, \& Solnit 53-64. 
Compared to the best-interests standard, the sex or wealth-based rules would be capable of even-handed application. By making the results of adjudication more predictable, such rules would also tend to discourage litigation. But the reduction of litigation would be achieved by substantially changing the spouses' relative bargaining power in private negotiations. A standard providing for maternal preference, for example, does more than affect the outcome of the small number of disputes that are actually litigated. It also gives mothers as a class more bargaining power than fathers in negotiations over custody. Therefore, in comparing some more determinate standard with the best-interests principle, it is not enough simply to suggest that fewer disputes will be litigated. One must also consider whether the effects of the alternative standards on private negotiations are desirable.

The best-interests-of-the-child standard provides a more "neutral" backdrop for both private negotiations and adjudication than a rule providing a preference on the basis of sex; and in my view, this is desirable. There appears to be no substantial empirical evidence to justify, from the child's perspective, a rule that systematically "tilts" the process in favor of the mother where the parents disagree: this was acknowledged by the leading proponents of a maternal-preference rule. ${ }^{240}$ Sex-based rules have been tried historically and are now being discarded (correctly in my view) because they reflect value judgments and sexual stereotypes that our society is in the process of rejecting. A wealth-based standard has similar weaknesses, for wealth and child rearing ability are not known to be coincident, and a test that preferred the richer parent for that reason alone would be seen as unfair. It might be thought that, other things being equal, a richer parent would be more likely to provide the child with certain material advantages. But child-support payments can be used to reallocate family wealth. Moreover, a wealth-based test would be offensive to many people, because they would see it as implicitly treating the child as a possession to be allocated by a market, even though the application of the standard itself would involve no exchange. ${ }^{241}$

A standard that awards custody to the parent able to spend more time with the child would ignore qualitative differences in time spent with the child and thus might not be justifiable from the perspective of what is good for the child. In all events, because the test would require a prediction of the amount of time each parent would spend with the child, it would be very difficult to

240. See R. LeVy, supra note 4 , at 223.

241. A more explicit market system might resolve custody disputes by an auction, with custody going to the parent who bid the most for the child, and the payments going to the other parent. Such a plan might be defended on the grounds that at least the loser would end up with money if not the child. Moreover, it might be thought desirable from the child's perspective to have the child go to the parent who wanted the child more. Because of differences in the relative. wealth of the two parents, however, as well as their other needs, comparing the bids of the two parents would not allow an accurate assessment and comparison of which one wanted the child more. 
apply and would invite exaggeration and dishonesty in litigation. Monitoring the time a parent would actually spend with a child after the custody dispute was resolved would be intrusive and impractical. Moreover, what remedy would there be if a parent later spent less time than expected? Removal of the child would be plainly undesirable from the child's perspective. The absence of a practical check suggests that this legal standard would invite the disputants to make unrealistically high estimates of how much time they would spend with the child and thus corrupt the process of adjudication.

Having the child choose has much to commend it. The child, after all, is the focus on social concern. Moreover, in the face of indeterminacy, why not have the child's values inform the choice? The child, better than the judge, may have an intuitive sense of the parent's love, devotion, and capacity. But particularly for infants, this standard is little more than a random process, and for the younger child, what would this standard mean? Would the child be able to express a preference? If so, would the child's choice be pressured or corrupted by the prelitigation behavior of one parent? Is it desirable or fair to ask the child to choose? This rule might make the child, in the parents' eyes, responsible for the choice. This might often be a very great burden for the child. Furthermore, if the child were made responsible, the child's relationship with the nonchosen parent might be substantially injured. Many states now require a judge to consider a child's expressed preference in applying the best-interests standard, and the choice of those young people twelve to fourteen years of age or older is by statute often made dispositive. ${ }^{242}$ Perhaps this age could be lowered, but in all events, the existing practice appears preferable to a rule that would require the child to choose and then make that choice determinative for all cases.

The final "standard"-choosing the parent whose psychological relationship with the child would be "less detrimental"-is suggested by Goldstein, Freud, and Solnit and represents the most recent of a related series of proposals that the insights of psychology and psychiatry be used as a basis for the reformulation of custody standards. ${ }^{243}$ My earlier formulation of the three

242. See note 149 supra.

243. Nearly twelve years ago, a seminal note in the Yale Law Journal argued that:

[O]ptimum custody goals [of the best-interests-of-the-child standard] may be further de-

fined by concentration on the psychological well-being of the child, where "psychological well-being" is used to denote the mental and emotional health of the child-specifically, a process of personality development within the framework of patterns of normal growth as posited by the behavioral sciences.

Note, Alternatives to "Parental Right" in Child Custody Disputes Involving Third Parties, 73 YALE L.J. 151,157 (1963). While suggesting that concern for the psychological welfare of the child, as opposed to the child's physical and material welfare, was implicit in the criteria sometimes referred to in cases applying the best-interests-of-the-child test, this note argued that courts should adopt a "psychological best interests test," $i d$. at 162; and that "further inquiry should be made into the fundamental relationship between 'psychological' parent and child. . . ." Id. at 160. Under a psychological best-interests test, it explained that: 
intermediate standards for private disputes reveals that I accept the conclusion that a "psychological parent" who is biologically unrelated to the child should prevail over a natural parent who is a stranger to the child. While the proposition has not been empirically proven, the risks of removing the child from a "psychological parent" for placement with a psychological "stranger" would seem to outweigh the psychological benefits the child might receive by maintaining a better sense of lineage by living with the natural parent. Moreover, I believe that psychologists and psychiatrists can rather consistently differentiate between a situation where an adult and a child have a substantial relationship of the sort we characterize as parent-child and that where there is no such relationship at all. But I do not think that existing psychological

[The] primary aim would be to identify and describe the existing affectionrelationship(s), chiefly from the perspective of the particular child who is the subject of the custody dispute. Such relationships might be inferred from evidence shedding light on three questions: the continuity of the relationship between child and adult in terms of proximity and duration; the love of the adult toward the child; and the affection and trust of the child toward the adult. . .

Id. at 162. A few years later-in 1968-Professor Joseph Goldstein, himself trained in both law and psychiatry, wrote:

If the law student (who is also hopefully the future judge) were to study the primary sources of psychoanalysis, he would see that at most and at best a psychoanalyticallyinformed definition of the child's best interest would assist court or adoption agency in deciding which disposition among available alternatives is likely to provide the child, whatever his endowments, with the best available opportunity to fulfill his potential in society as a civilized human being.

Goldstein, Psychoanalysis and Jurisprudence, 77 YALE L.J. 1053, 1076 (1968). And Professor Andrew $\mathrm{S}$. Watson has suggested the appropriate roles for expert witnesses, lawyers, and judges in custody disputes and described various factors that would be relevant to the application of a psychological best-interests-of-the-child test. See Watson, supra note 5 .

There has been some movement to reformulate juvenile neglect and dependency standards on the basis of psychology as well. A few states have amended their child-neglect statutes expressly to include "emotional" neglect. The Minnesota statute, for example, defines a neglected child in part as one whose parents "have substantially and consistently neglected to provide the child with necessary subsistence, education, or other care necessary for his physical or mental health or morals." Minn. STAT. ANw. $\$ 260.221$ (b)(3) (Supp. 1975) (emphasis added). The Idaho statute allow's a court to assume jurisdiction over a child "whose behavior indicates social or emotional maladjustment," which is defined as "the condition of a child who has been denied proper parental love, or adequate affectionate parental association, and who behaves unnaturally and unrealistically in relation to normal situations, objects and other persons." IDAHo Code ANN. § 16-1625-26 (Supp. 1975). And Professor Sanford Katz has suggested that the example of these states be followed by others:

[It would be] highly desirable that legislative recognition be given to "emotional neglect" as an independent legal standard. This view is a result of experience showing a judicial reluctance to carve out categories of neglect that are not thoroughly provided for in the statute itself. Specific statutory reference to mental health would provide the needed "peg" upon which to hang a finding of emotional deprivation.

S. Katz, supra note 68 , at 67-68. On the question of how' specific the definition of the emotional neglect should be, he revealingly states: "Because we have not yet acquired sufficient knowledge about normal and abnormal child development, it is not suggested that an elaborate or detailed definition of "emotional neglect be frozen into a statute." Id. at 68 . He does not satisfactorily explain, however, why emotional neglect should be a basis for child protection if it cannot be defined. In my view, these definitional difficulties caution against making emotional neglect a basis for child-protection. See text at notes 222-23 supra. 
theories provide the basis to choose generally between two adults where the child has some relationship and psychological attachment to each.

Having custody disputes determined by embracing more and more of the niceties of psychological and psychiatric theories requires careful analysis of the limits of these theories, their empirical bases, and the capacity of our legal system to absorb this new doctrine. ${ }^{244}$ In cases where, from the child's perspective, each claimant has a psychological relationship with the child, I doubt whether there would often be widespread consensus among experts about which parent would prove psychologically better (or less detrimental) to the child. Often each parent will have a different sort of relationship with the child, with the child attached to each. One may be warm, easy-going, but incapable of discipline. The other may be fair, able to set limits, but unable to express affection. By what criteria is an expert to decide which is less detrimental? Moreover, even the proponents of psychological standards have acknowledged how problematic it is to evaluate relationships from a psychological perspective unless a highly trained person spends a considerable amount of time observing the parent and child interact or talking to the child. ${ }^{245} \mathrm{Su}$ perficial examinations by those without substantial training may be worse than nothing. And yet, that is surely a high risk.

Even with the best trained experts, the choice would be based on predictions that are beyond the demonstrated capacity of any existing theory. ${ }^{246}$ While the psychologists and psychiatrists have made substantial therapeutic contributions, they are not soothsayers capable of predicting with any degree of confidence how a child is likely to benefit from alternative placements. When the expert does express a preference, it too often is based on an unexpressed value preference. What is psychologically least detrimental will usually be no more determinate for expert and nonexpert alike than what is in a child's best interests; and to reframe the question in a way that invites predictions based on the use of labels and terminology developed for treatment is both demeaning to the expert and corrupting for the judicial process.

\section{Negotiation and Mediation}

The problems posed by the use of an indeterminate standard, coupled with the difficulties of formulating more precise rules that would dispose of

244. Cf. Bok, Section 7 of the Clayton Act and the Merging of Law and Economics, 74 HARv. L. REv. $226(1960)$.

245. See Watson, supra note 5, at 74-77.

246. Goldstein, Freud, and Solnit emphasize the predictive limitations of existing theory. Goldstein, Freud, \& Solvit 51-53. But their "guidelines" do not facilitate choice in any but the easy case where one claimant is a psychological stranger to the child. Nevertheless, the model placement statute suggested invites inquiry into which of two psychological parents is least detrimental. See id. at 99, 100. While these proposed guidelines generally put upon the intervenor the burden of establishing that a child is not wanted, this is not so "in custody disputes in divorce or separation," where the court would instead be asked to decide which parent was "the least detrimental available alternative." $I d$. at 100 . 
many cases, invite explicit consideration of modes of dispute resolution other than traditional adjudication. Since a primary goal for cases of these sorts should be facilitating private resolutions, mediation is an obvious possibility. A negotiated settlement has considerable advantages over one imposed by a court. The adults seeking custody avoid the cost-both financial and emotional-of an adversary proceeding.

Divorcing parents often negotiate and agree about child custody while simultaneously settling other issues such as visitation, child support, and marital property division. ${ }^{247}$ The eventual agreement about custody may often be a reflection of the parents' interests in these other matters, rather than the child's. Nevertheless, as an operating rule, it seems plain that a negotiated resolution is preferable from the child's perspective for several reasons. Since a child's social and psychological relationships with both parents ordinarily continue after the divorce, a process that leads to agreement between the parents is preferable to one that necessarily has a winner and a loser. A child's future relationship with each of his parents may be better maintained and his existing relationship less damaged by a negotiated settlement than by one imposed by a court after an adversary proceeding. Moreover, the parents will know more about the child than the judge, since they have better access to information about the child's circumstances and desires. Indeed, given the basic indeterminacy of anyone knowing what is best for the child, having a privately negotiated solution by those who will be responsible for care after the divorce seems much more likely to match the parents' capacities and desires with the child's needs. These advantages suggest that courts should not second-guess parental agreements unless judicial intervention is required by the strict child-protection standard suggested below. ${ }^{248}$

The advantages of a negotiated resolution also suggest the desirability of changes that would facilitate and encourage parental resolution of disagreements about custody. One can imagine a variety of extreme ways by which the legal system might put additional pressure on parents to reach a negotiated resolution. For example, the state might refuse to grant a divorce where there are children unless the parents have agreed on custodial arrangements. Alternatively, the state might charge very onerous fees (geared to the wealth of the parties) for adjudication of child-custody disputes. As a consequence of such extreme rules, however, more parents might separate without divorce and use force or other extralegal means to gain physical custody of the child. Less extreme changes might involve greater use of some form of mediation. Mediators or family counselors (perhaps attached to a court) could adopt as

247. See, e.g., Watson, supra note 5 , at 59.

248. I thus reject the suggestion that there be independent investigations and intensive judicial examination of consensual arrangements. See Leavall, Custody Disputes and the Proposed Model Act, 2 GA. L. REV. 162, 190-91 (1968). 
their goal parental resolution of the custody dispute, rather than the broader tasks of "curing" or "treating" the parents or saving the marriage. ${ }^{249}$ But existing evidence on "conciliation courts" should caution against a view of mediation as a bold and heroic scheme destined to solve most of the custody disputes adjudicated today. ${ }^{250}$

\section{Informal Adjudication}

Even if mediation is successful in some cases, unresolved disputes will remain. For these disputes, is "formal adjudication" ${ }^{51}$ - where the judge is a stranger to the parties-the best mechanism? In the application of a broad, person-oriented standard, a more "intimate" form of adjudication or arbitration might be highly desirable. ${ }^{252}$ If the disputing parents could agree on the choice of a "judge" and the "judge" knew the family, the custody decision might better reflect an intuitive appreciation of the parties' values, psychology, and goals. The decision might also be more acceptable to the parents.

In closely-knit communities, a "patriarch," "matriarch," or "leader" known to and respected by both parties would be an excellent person for deciding a custody dispute that the parents could not resolve. But this sense of community and intimacy may be scarce in twentieth-century America. Moreover, many "intimates" acceptable to both parents would no doubt decline the anguishing responsibility of deciding who should have custody. In short, although a more intimate form of adjudication might be desirable, it is unclear that such a system could be implemented on a broad scale.

\section{Random Selection}

Assuming that an "intimate" acceptable to both parents cannot be found to make an individualized decision, would not a random process of decision be fairer and more efficient than adjudication under a best-interests principle? ${ }^{253}$ Individualized adjudication means that the result will often turn on a largely intuitive evaluation based on unspoken values and unproven predictions. We would more frankly acknowledge both our ignorance and the presumed equality of the natural parents were we to flip a coin. Whether one had a

249. Most proposals for family courts appear to be bottomed on a therapeutic model. See Kay, supra note 181 , at $1208,1244$.

250. See Maddi, The Effect of Conciliation Court Proceedings on Petitions for Dissolution of Marriage, 13 J. Family LaW 495 (1974).

251. See note 128 supra.

252. See id.; cf. Kubie, Provisions for the Care of Children of Divorced Parents: A New Legal Instrument, 73 YaLE L.J. 1197 (1964), proposing decision by a committee of specialists selected by the parties with the power to make a binding determination, which is further discussed in Note, Committee Decision of Child Custody Disputes and the Judicial Test of "Best Interests," 73 YALE L.J. 1201 (1964).

253. See Goldstein, Freud, \& Solvit 153; Coons, Approaches to Court Imposed Compromise-the Uses of Doubt and Reason, 58 Nw. U.L. REv. 750 (1964). 
separate flip for each child or one flip for all the children, the process would certainly be cheaper and quicker. It would avoid the pain associated with an adversary proceeding that requires an open exploration of the intimate aspects of family life and an ultimate judgment that one parent is preferable to the other. And it might have beneficial effects on private negotiations. ${ }^{254}$

Resolving a custody dispute by state-administered coin-flip would probably be viewed as unacceptable by most in our society. Perhaps this reaction reflects an abiding faith, despite the absence of an empirical basis for it, that letting a judge choose produces better results for the child. Alternatively, flipping a coin might be unacceptable for some because it represents an abdication of the search for wisdom. While judgments about what is best for the child may be currently beyond our capacity in many cases, this need not be true in fifty years. Movement towards better judgments implies, however, that judges and decision-makers as a group learn from the process of decision. In the absence of systematic feedback, this is not likely. Indeed, adopting a coinflip now means neither that at a time when more were known and a consensus existed an adjudicatory system might not be adopted, nor that efforts to discover an adjudicatory standard would cease.

Deciding a child's future by flipping a coin might be viewed as callous. Is it more callous, however, than drafting for the military by lottery: In the same way that a lottery is a social affirmation of equality among those upon whom the government might impose the risks of war, a coin-flip would be a government affirmation of the equality of the parents. In a custody case, however, a coin-flip also symbolically abdicates government responsibility for the child and symbolically denies the importance of human differences and distinctiveness. Moreover, flipping a coin would deprive the parents of a process and a forum where their anger and aspirations might be expressed. In all, these symbolic and participatory values of adjudication would be lost by a random process.

While forceful arguments can be made in favor of the abandonment of adjudication and the adoption of an openly random process, the repulsion

254. The effect on negotiation would depend on each parent's risk preferences and on how much each wanted the child. Because each parent would face a 50 per cent chance of losing, this might encourage private compromise if both wanted the child and were very risk-averse. But because a coin-flip would be less painful than an adversary proceeding the threat of holding out for such a resolution might be more frequently and credibly used than the threat of litigation is today by a party who did not much want the child but who was bargaining for advantage with regard to other elements of the marriage dissolution. To avoid these bargaining problems, the state might insist that the coin-flip occur at the time of the marriage. Through a state-supervised random process, one of the parents could then be designated as the parent who would have custody (absent a showing of neglect) if the parents should later separate and be unable themselves to decide who should have custody. For children of unmarried parents, the rule of maternal preference might be kept. The winner of the coin-flip would, of course, have an enormous negotiating advantage. It is interesting to speculate whether such a rule would affect the loser's emotional commitment to the child or willingness to stay married to avoid losing custody of the child. 
many would probably feel towards this suggestion may reflect an intuitive appreciation of the importance of the educational, participatory, and symbolic values of adjudication as a mode of dispute settlement. Adjudication under the indeterminate best-interests principle may yield something close to a random pattern of outcomes, while at the same time serving these values, affirming parental equality, and expressing a social concern for the child. Insofar as judges as a group may have value preferences that systematically bias the process and make the pattern less than random, these value preferences may reflect widespread values that have not been acknowledged openly in the form of legal rules.

\section{Conclusion}

This paper has developed a pair of themes: (1) Courts perform two different functions in the resolution of child-custody disputes: child-protection and private-dispute-settlement. (2) In child-custody disputes, the determination of what is "best" or "least detrimental" for a particular child is usually indeterminate. In exploring these two themes and their interaction, the primary goal has been to provide analytical tools that will contribute to a better understanding of the problems of American custody law. The analysis does have policy implications for the custody area, and the tools may have usefulness beyond the analysis of custody disputes. A few concluding paragraphs therefore seem in order.

If one accepts the proposition that courts may perform two different functions in custody disputes and that different considerations should inform the operation of each, then one implication is that substantive or procedural changes that confound the distinction between private dispute resolution and child protection should be avoided. This means, for one thing, that there should not be a single substantive standard (such as the best-interests-of-thechild principle) to govern all custody disputes. It also suggests that the creation of a single family court to hear all custody cases may be an institutional reform that risks blurring the distinction between the two functions and inviting overly broad judicial intervention for child protection purposes in private disputes.

The distinction between the two functions also suggests that existing custody law (with separate strands for divorce, guardianship, juvenile neglect, and termination) may be unnecessarily complex. For cases requiring the private-dispute-settlement function, should the governing legal standards vary depending upon the "fortuity" of the legal setting and the doctrinal strand invoked? I am not prepared to recommend that all private custody disputes could necessarily be governed by an identical legal standard, because the legal consequences for the parent-child relationship differ depending upon the nature of the proceeding. Nevertheless, many of the same sorts of considerations are involved for all private custody disputes, irrespective of the strands 
of law invoked. Indeed, for any private custody dispute, the primary implication of the indeterminacy of the best-interests standard is that the legal process should encourage the parties themselves to work out their own resolution.

Where the parties cannot agree, there is an obvious need for some mechanism for the resolution of private custody disputes. "Intermediate rules" make the resolution by adjudication of some private disputes relatively straightforward. But the resolution of most private disputes by adjudication poses a genuine dilemma. On the one hand, the very inability to make predictions about the consequences of alternative custody dispositions and the lack of a social consensus about the values that should inform child rearing make the formulation of rules - by the court or the legislature--very problematic at the present time. On the other hand, the use of an indeterminate standard such as "best interests" raises fundamental questions of fairness, largely removes the special burden of justification that is characteristic of adjudication, and involves the use of the judicial process in a way that is quite uncharacteristic of traditional adjudication. Consequently, for private disputes that cannot be disposed of by acceptable intermediate rules, resolution by informal adjudication or random process are two radical alternatives to the status quo that are worthy of serious consideration. But neither offers assurance of being plainly superior to adjudication under the indeterminate best-interests principle.

Because abandonment of adjudication for the resolution of private custody disputes seems unlikely, I offer the following modest, but perhaps reassuring, advice to judges responsible for applying the best-interests standard in private disputes: the judicial task is to resolve the private dispute because the parties cannot settle the matter themselves. High on the agenda of any reform effort should be those changes directed toward insuring that courts better fulfill their primary obligation, which is to decide, decide promptly, and decide once and for all.

For the child-protection function, legal standards define the circumstances that justify coercive governmental intervention into the family in particular. Here, the use of indeterminate standards is unjust and unwise. It provides the state with too much power to intervene into the family, and it has very adverse consequences for children who have been removed from parental custody for reasons of child protection. That the purpose of coercive state intervention is high-minded and for the benefit of the child does not justify the failure to develop better defined legal standards that limit the wide discretion presently given to professionals involved in juvenile court child-neglect proceedings and the foster-care system.

There are costs associated with limiting this discretion. Some children who might substantially benefit from coercive removal from parental custody might be excluded from the foster-care system under more precise standards 
for child protection. Similarly, under the sorts of time-based standards that I propose, there may be children freed for adoption who would be better off if left in foster care for a longer period and eventually returned to parental custody. The underlying issue in either circumstance, however, is whether we can make the refined sort of judgments necessary to identify those children. Because such individualized judgments cannot be confidently made, more precise legal standards for initial intervention and for controlling what was to happen to children after removal would produce a fairer system and one that, on balance, was more helpful to children.

The themes developed in this paper have relevance beyond the childcustody area. The best-interests-of-the-child principle is invoked elsewhere by state officials. For example, it is the standard typically used by the judge who must decide what is to become of the juvenile offender. Public school officials often invoke the same principle when deciding what reading group or academic track or kind of education a particular child should have. More generally, there are a variety of child-protective laws relating to areas like child labor and compulsory education, which limit the power of the family to decide, that are sometimes justified on the basis of the interests of children and their need for protection.

While this analysis certainly points to no clear-cut answers to the various policy problems that our society confronts in these other areas, the themes developed here do suggest some highly relevant questions. In many of these other settings, it is useful to ask whether there are interests other than those of children that are at stake. Is the vague best-interests principle in fact being used to shelter from explicit analysis other (often appropriate) considerations? Moreover, to the extent that the interests of children should be treated as paramount, is there a basis for determining what is best for an individual child or children as a group? I suspect that often what is best in these other areas is as indeterminate as it is in child-custody disputes. There will often be a similar absence of well recognized means to predict how individual children are affected by and will react to common phenomena. Moreover, the same lack of consensus about values that plagues child-custody law may make the formulation of policy in these other areas problematic. Thus, as is true in child custody, the fundamental question may be: if what is best for an individual child is largely indeterminate, how should law distribute the power of decision among the child, the family, and the state. 
